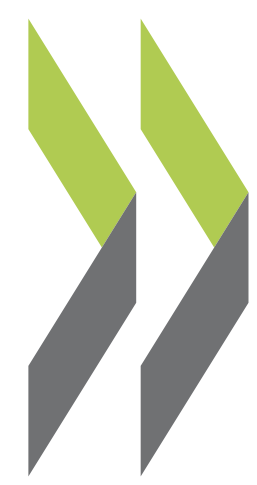

OECD Economics Department Working Papers No. 1245

Enhancing the financing

of the real economy

and financial stability

Olena Havrylchyk,

in the United Kingdom 
Organisation de Coopération et de Développement Économiques

Organisation for Economic Co-operation and Development

06-Jul-2015

ECONOMICS DEPARTMENT

English - Or. English

ENHANCING THE FINANCING OF THE REAL ECONOMY AND FINANCIAL STABILITY IN THE UNITED KINGDOM

ECONOMICS DEPARTMENT WORKING PAPERS No. 1245

By Olena Havrylchyk and Rafał Kierzenkowski

OECD Working Papers should not be reported as representing the official views of the OECD or of its member countries. The opinions expressed and arguments employed are those of the author $(s)$.

Authorised for publication by Robert Ford, Deputy Director, Country Studies Branch, Economics Department.

All Economics Department Working Papers are available at www.oecd.org/eco/workingpapers

JT03379872

Complete document available on OLIS in its original format

This document and any map included herein are without prejudice to the status of or sovereignty over any territory, to the delimitation of international frontiers and boundaries and to the name of any territory, city or area. 
OECD Working Papers should not be reported as representing the official views of the OECD or of its member countries. The opinions expressed and arguments employed are those of the author(s).

Working Papers describe preliminary results or research in progress by the author(s) and are published to stimulate discussion on a broad range of issues on which the OECD works.

Comments on Working Papers are welcomed, and may be sent to the Economics Department, OECD, 2 rue André-Pascal, 75775 Paris Cedex 16, France, or by e-mail to eco.contact@oecd.org.

All Economics Department Working Papers are available at www.oecd.org/eco/workingpapers.

This document and any map included herein are without prejudice to the status of or sovereignty over any territory, to the delimitation of international frontiers and boundaries and to the name of any territory, city or area.

The statistical data for Israel are supplied by and under the responsibility of the relevant Israeli authorities. The use of such data by the OECD is without prejudice to the status of the Golan Heights, East Jerusalem and Israeli settlements in the West Bank under the terms of international law.

\section{OECD (2015)}

You can copy, download or print OECD content for your own use, and you can include excerpts from OECD publications, databases and multimedia products in your own documents, presentations, blogs, websites and teaching materials, provided that suitable acknowledgment of OECD as source and copyright owner is given. All requests for commercial use and translation rights should be submitted to rights@oecd.org 


\section{ABSTRACT/RÉSUMÉ \\ Enhancing the Financing of the Real Economy and Financial Stability in the United Kingdom}

The banking sector in the United Kingdom (UK) was deeply affected by the crisis. Bank credit has collapsed reflecting both weak demand and tighter supply. New prudential requirements have improved the resilience of the banking sector and a number of measures were taken to support credit supply. These included conventional and unconventional monetary policies, policies to address credit constraints with Help to Buy and Funding for Lending programmes, and a number of public programmes to improve access to finance united under the roof of the British Business Bank. Further structural reforms are needed to improve competition in the SME credit market and to boost credit provision to SMEs in the medium term. Sustainable financing of the economy and greater financial stability should be achieved by sound regulation, ensuring high capital requirements for systemically important banks, improving banks' resolvability and fine-tuning the use of countercyclical measures. Data should be collected on a wider set of financial institutions than currently done and macroprudential regulation should be gradually extended beyond the banking sector to prevent the migration of systemic risks.

This Working Paper relates to the 2015 OECD Economic Survey of the United Kingdom (www.oecd.org/eco/surveys/economic-survey-united-kingdom.htm)

JEL classification: G21, G28, D14, D24

Keywords: OECD, United Kingdom, banks, access to finance, mortgages, business lending, SMEs, households, capital, deleveraging, house prices, financial stability.

$* * * * * * * * * * * * * * * *$

\section{Renforcer le financement de l'économie réelle et la stabilité financière au Royaume-Uni}

Le secteur bancaire du Royaume-Uni a été profondément touché par la crise. Les concours bancaires ont chuté, sous l'effet de la faiblesse de la demande aussi bien que des restrictions de l'offre. Les nouvelles obligations prudentielles ont cependant amélioré la résilience du secteur bancaire, et les pouvoirs publics ont pris un certain nombre de mesures pour soutenir l'offre de crédit, parmi lesquelles des mesures de politique monétaire conventionnelles et non conventionnelles, des mesures visant à alléger les contraintes pesant sur l'accès au crédit grâce aux programmes Help to Buy et Funding for Lending, ainsi que plusieurs programmes publics destinés à assouplir le crédit aux entreprises, regroupés sous l'égide de la British Business Bank. D'autres réformes structurelles sont nécessaires pour améliorer la concurrence sur le marché du crédit aux PME et stimuler les concours aux petites et moyennes entreprises à moyen terme. Il faudrait parvenir à assurer un financement durable de l'économie et une plus grande stabilité financière par l'adoption d'une réglementation solide, l'imposition de normes d'adéquation des fonds propres aux banques d'importance systémique, l'amélioration des possibilités résolution en cas de difficultés et d'affiner le recours aux mesures contra-cycliques. Il conviendrait aussi de recueillir des données portant sur un nombre d'institutions financières plus grand que ce qui est actuellement fait, et la réglementation macroprudentielle devrait être progressivement élargie au-delà du secteur bancaire afin de prévenir la diffusion des risques systémiques.

Ce Document de travail se rapporte à l'Étude économique de l'OCDE du Royaume-Uni, 2015 (www.oecd.org/fr/eco/etudes/etude-economique-royaume-uni.htm)

Classification JEL: G21, G28, D14, D24

Mots clefs: OCDE, Royaume-Uni, banques, accès au financement, prêts hypothécaires, crédit aux entreprises, PME, ménages, fonds propres, désendettement, prix immobiliers, stabilité financière. 


\section{TABLE OF CONTENTS}

\section{ENHANCING THE FINANCING OF THE REAL ECONOMY AND FINANCIAL STABILITY IN THE

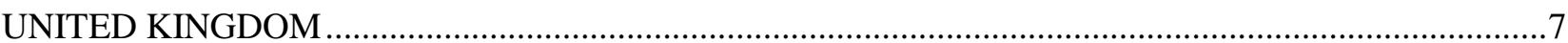

The banking sector is recovering but the financing of the real economy remains impaired........................7

The health of the banking sector was deeply affected by the crisis .....................................................

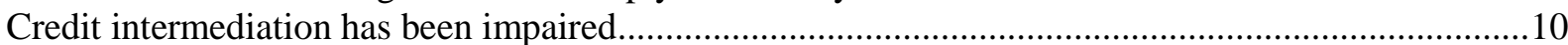

Lending by new credit providers does not substitute for bank financing .......................................12

Improving access to bank loans and smoothing the credit cycle .........................................................13

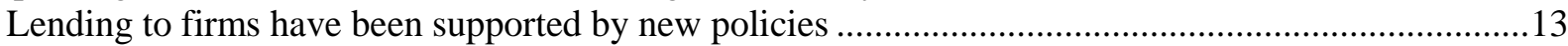

Lending support to households has contributed to housing market recovery ……...............................18

Macro-prudential regulation should prevent imbalances and help smooth the credit cycle...................21

Reducing risks posed by the financing system via sound regulation ...................................................24

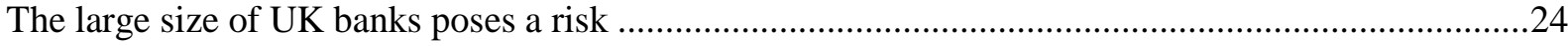

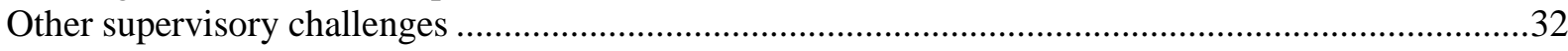

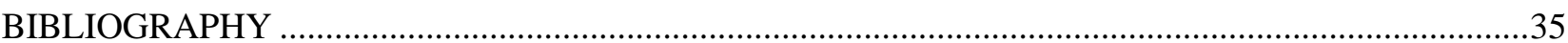

\section{Tables}

1. Loans provided by monetary financial institutions and new credit providers ................................12

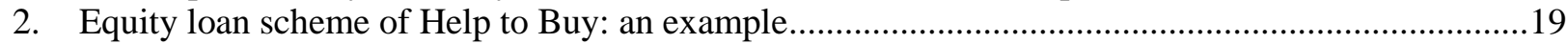

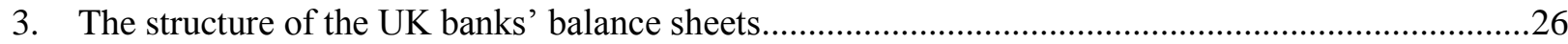

4. Fines and settlements as well as provisions for litigation costs of banks have been high ..................34

\section{Figures}

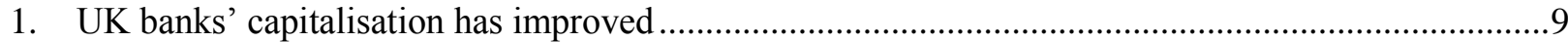

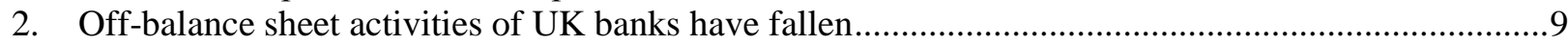

3. Net loan growth of monetary financial institutions has been weak ................................................10

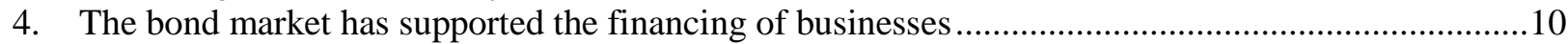

5. Lending to UK SMEs has not recovered since the crisis..............................................................11

6. Businesses face lower bank lending rates, but higher risk premiums..............................................11

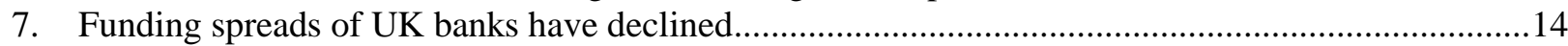

8. Corporate and household credit availability has been improving until recently ...............................15

9. Underwriting standards developments have been mixed..............................................................2

10. House prices have been buoyant and are high relative to incomes and rents ..............................20

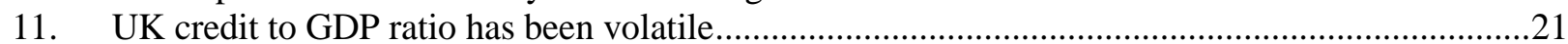

12. Relationship between leverage ratio and funding costs of global systemic banks ..........................24

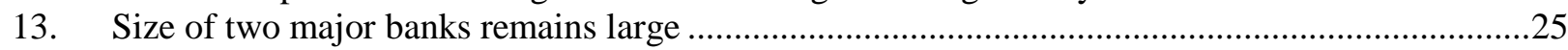

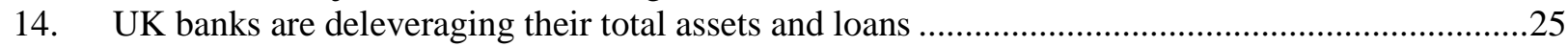


15. Loans to non-financial corporations are low and are high for households .27

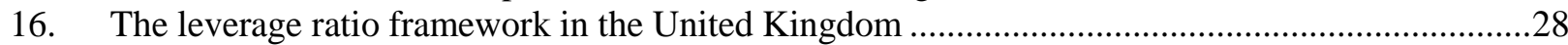

17. Global systemic risk of the UK financial sector is large ..................................................................

\section{Boxes}

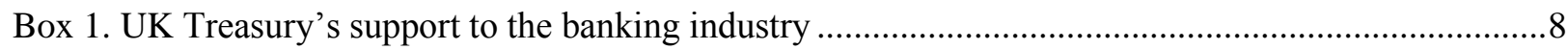

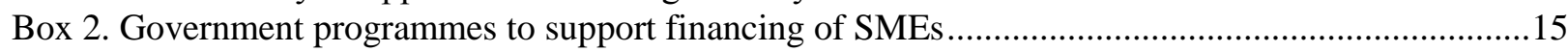

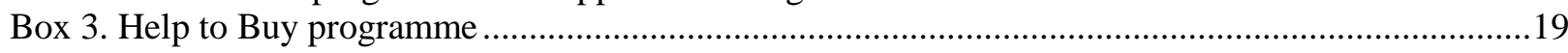

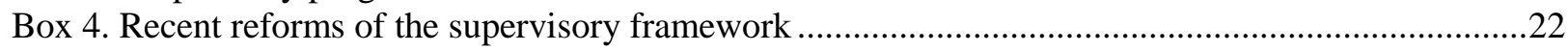

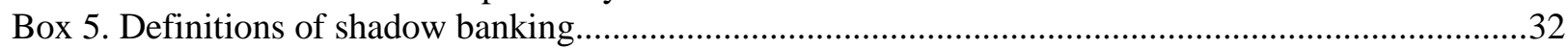

Box 6. Policy recommendations to ensure sustainable lending and financial stability ..............................35 
ECO/WKP(2015)63 
ECO/WKP(2015)63

\title{
ENHANCING THE FINANCING OF THE REAL ECONOMY AND FINANCIAL STABILITY IN THE UNITED KINGDOM
}

\author{
By Olena Havrylchyk and Rafał Kierzenkowski ${ }^{1}$
}

\section{The banking sector is recovering but the financing of the real economy remains impaired}

\section{The health of the banking sector was deeply affected by the crisis}

The pre-crisis model of UK banks was based on high leverage, short-term funding and relatively lenient financial regulation and supervision. For example, large repurchase agreements (temporary sale of securities in return for cash) contributed to excessive leverage of Northern Rock, exposing the bank to a liquidity run that was at the heart of its collapse (Shin, 2009). The failure of the Royal Bank of Scotland (RBS) was also caused by overreliance on short-term wholesale funding, reinforced by rapid growth via acquisitions of other banks and poor investment regarding credit-default swaps (insurance against credit events) (FSA, 2011). The framework of bank regulation and supervision of the Financial Services Authority, at the time referred to as "light-touch" regulation, was based on excessive confidence in self-regulation of financial markets (FSA, 2011). As a result, banks did not have sufficient capital and liquidity buffers to withstand the, admittedly very large, shocks in 2008 and 2009.

To prevent the collapse of the banking industry, the Treasury put in place a number of support measures (Box 1) to: i) recapitalise RBS and the Lloyds Banking Group (LBG); ii) protect depositors; and iii) provide guarantees and liquidity support to banks. According to the National Audit Office, guarantees amounted to about $65 \%$ of gross domestic product (GDP), while direct cash support stood at almost $10 \%$ of GDP. On the top of that, the Bank of England (BoE) introduced a range of conventional and unconventional monetary policy measures that further helped to stabilise banks.

1. This paper originally appeared as Chapter 2 in the OECD Economic Survey of the United Kingdom 2015, published in February 2015 under the authority of the Economic and Development Review Committee. Olena Havrylchyk is an external consultant and Rafał Kierzenkowski is Head of the United Kingdom desk at the OECD. The authors are also grateful to Pierre Beynet, Robert Ford, and Álvaro Pereira for valuable comments and suggestions on earlier drafts, as well as for discussions with British government officials and independent experts. Special thanks go to Gábor Fulop for statistical assistance and to Sylvie Ricordeau and Krystel Rakotoarisoa for editorial assistance. 


\section{Box 1. UK Treasury's support to the banking industry}

According to the National Audit Office, the Treasury's support to the banks included:

Recapitalisation of the Lloyds Banking Group (LBG) and the Royal Bank of Scotland (RBS) through a series of transactions eventually acquiring $83 \%$ of the latter (68\% of the voting rights) and $41 \%$ of the former (of both ordinary shares and voting rights).

Lending money to the Financial Services Compensation Scheme so it could guarantee customer deposits of up to GBP 50000 .

Lending directly to insolvent banks so they could repay customer deposits of over GBP $\mathbf{5 0} 000$, including to London Scottish Bank, Dunfermline Building Society and several Icelandic Banks (Heritable, Kaupthing Singer and Friedlander, and Landsbanki).

Nationalising Northern Rock and Bradford \& Bingley to protect their depositors and facilitate the orderly unwinding of their obligations and the Treasury's guarantees.

Operating the Special Liquidity Scheme, between April 2008 and January 2012, to increase the liquidity of UK banks. It was a Bank of England's scheme, supported by a Treasury guarantee, under which banks swapped assets for more liquid Treasury Bills in return for a fee.

Running the Credit Guarantee Scheme, between October 2008 and October 2012, to help restore investor confidence in bank wholesale funding by guaranteeing certain unsecured debts in return for a fee.

Implementing the Asset Protection Scheme, from January 2009 to October 2012, to protect assets on banks' balance sheets. RBS and LBG initially agreed to join, but in the end only RBS did.

Since then, the total level of state intervention has been reduced significantly owing to net repayments of support by banks, the sale of the Northern Rock to Virgin Money at the end of 2011, and a partial privatisation of LBG. Nevertheless, the government remains the majority owner of RBS and defining a schedule to a full return of the bank to the private sector would be a step in the right direction. Capital and funding positions of banks have strengthened since the crisis but risks remain

Banks' risk-weighted capital ratios have risen significantly, partly owing to declines in risk weights and state recapitalisation. The core Tier 1 capital ratio increased from $6 \%$ of risk-weighted assets in 2007 to $12 \%$ in 2013 (Figure 1). This rise occurred due to reduced lending, asset divestment, and increases in additional capital primarily financed by the government given difficulties to tap private sources of capital. Moreover, risk-weighted assets diminished due to the continued decline of average risk weights that fell from about $50 \%$ in 2003 to $35 \%$ in 2007 , but have recovered somewhat since then (Figure 1). The precrisis decline in risk-weights was due to the transition from Basel I to Basel II capital requirements (particularly the adoption of internal rating-based models, which have allowed banks to rely on lower risk weights), which was completed for most banks in 2008. In the aftermath of the crisis, a number of banks have increased their holdings of sovereign assets, which has contributed to lower risk weights.

Banks' leverage ratio has also increased, but given the lesson of the crisis that high equity is needed to withstand major shocks, the improvement could be considered as moderate. Simple leverage ratio (capital to unweighted assets) rose from close to $3.5 \%$ in 2007 to almost $6 \%$ in the first half of 2014, a comparatively more modest increase than that of the risk-weighted capital ratio. Moreover, the average leverage ratio stood at only $4 \%$ in 2013 if one applies a stricter definition of capital proposed by the Basel III rules. Reflecting diminishing uncertainty about potential unrecognised losses, the market valuation of capital has finally recovered to slightly above the book value (as of September 2014), but this still results in very low market-based leverage ratio when compared to the pre-crisis period. Developments in leverage ratios are important because they appear to be superior predictors of future bank problems than risk-weighted capital ratios (Blundell-Wignall and Roulet, 2013; Haldane, 2011a, 2012). 
Figure 1. UK banks' capitalisation has improved

Per cent ${ }^{1}$

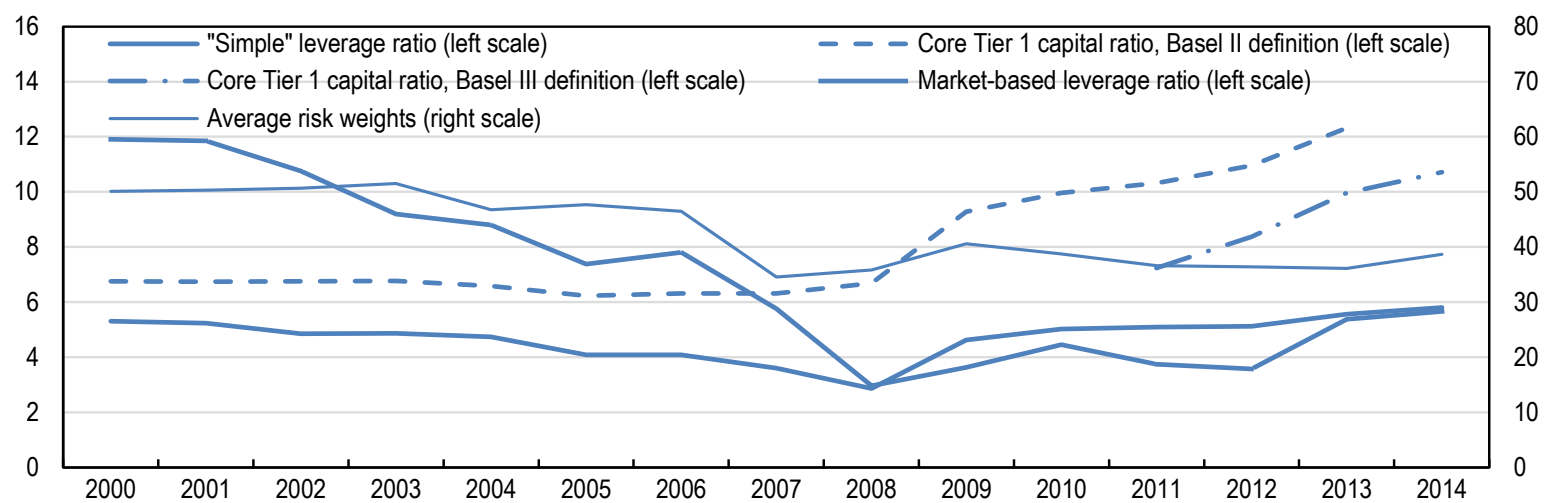

1. Figures for "simple" leverage ratio, Core Tier 1 capital ratio (Basel III definition) and average risk weights for 2014 refer to first half of 2014. "Simple" leverage ratio is calculated as aggregate peer group equity (shareholders' claims) over aggregate peer group assets. Core Tier 1 capital ratio (Basel II definition) refers to major UK banks' aggregate core Tier 1 capital as a percentage of their aggregate risk-weighted assets. The Basel II series was discontinued on 1 January 2014. Core Tier 1 capital ratio (Basel III definition) is calculated as aggregate peer group common equity Tier 1 levels over aggregate risk-weighted assets. Market-based leverage ratio is calculated as total peer group market capitalisation divided by total peer group assets (note a discontinuity due to introduction of International Financial Reporting Standards (IFRS) accounting standards in 2005, which tends to reduce leverage ratios thereafter). Average risk weights are calculated by dividing aggregate peer group risk-weighted assets by aggregate peer group assets.

Source: Bank of England (2014), "Financial Stability Report, December 2014", Issue No. 36, December.

Fragilities of the banking sector related to short-term wholesale funding and reliance on securitisation have declined. The share of wholesale funding in total banks' assets fell from nearly 30\% in 2007 to $15 \%$ in 2013. Securitised loans shrank by more than 50\% between January 2010 and December 2014 (Figure 2). In parallel, banks' investment in their own special purpose vehicles (SPVs) or so-called "conduits" (entities that issued short-term debt to finance long-term off-balance sheet bank assets) collapsed by two-thirds. The decline in securitisation was caused by increased risk aversion and tighter regulation, which notably removed the possibility of regulatory arbitrage that was prevalent before the crisis when conduits were set up to avoid capital regulation, as discussed below.

Figure 2. Off-balance sheet activities of UK banks have fallen GBP billion ${ }^{1}$

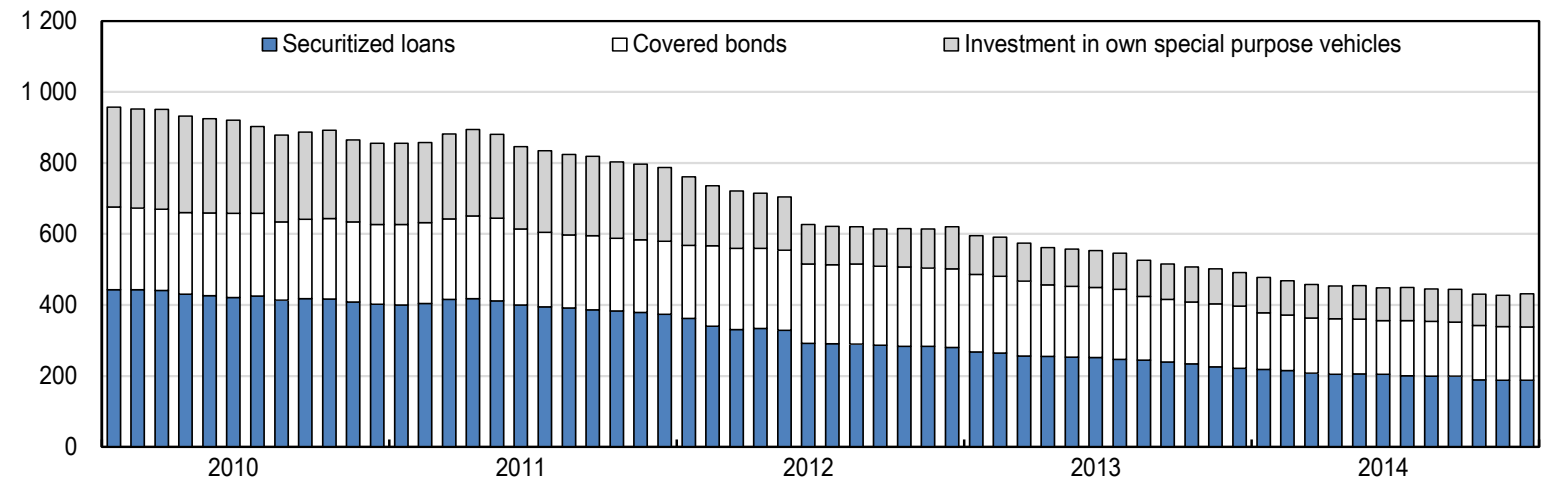

1. The chart presents data on monetary financial institutions' (MFI) loans that are securitised or ring-fenced for covered bond programmes, and MFI holdings of securities issued by own special purpose vehicles (SPVs). The data presented cover only securitisation SPVs that are owned by UK MFIs, and do not cover all SPVs resident in the UK. Securitisation SPV mean any undertaking which: i) is organised to carry out one or more securitisation transactions; and ii) issues, or may issue, securities and/or which holds, or may hold, assets underlying the issue of securities that are offered for sale to the public, sold on the basis of private placements, or held by the institution that originated the underlying assets. Data are not seasonally adjusted.

Source: Bank of England (2015), "Monetary and Financial Statistics", Statistical Interactive Database, January. 


\section{Credit intermediation has been impaired}

The crisis has hampered credit intermediation, especially lending to the business sector. Net lending to businesses has been falling since 2009, declining more for large businesses than for small and medium-sized enterprises (SMEs) (Figure 3). Large businesses were able to rely on the bond market that has remained rather healthy during the post-crisis years (Figure 4), but this was not sufficient to substitute for a dramatic fall in bank lending (Grjebine et al., 2014).

Figure 3. Net loan growth of monetary financial institutions has been weak

Per cent ${ }^{1}$

A. Bank lending has been hit by the crisis ${ }^{2}$

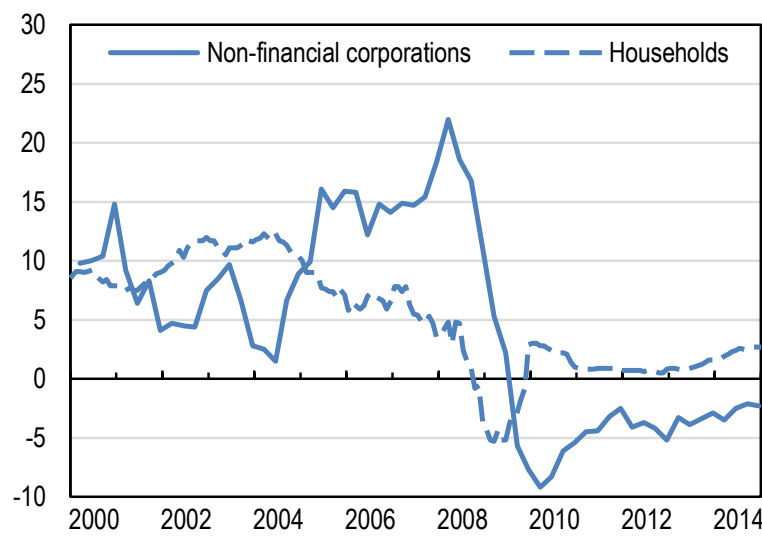

B. Large and small firms get fewer loans ${ }^{3}$

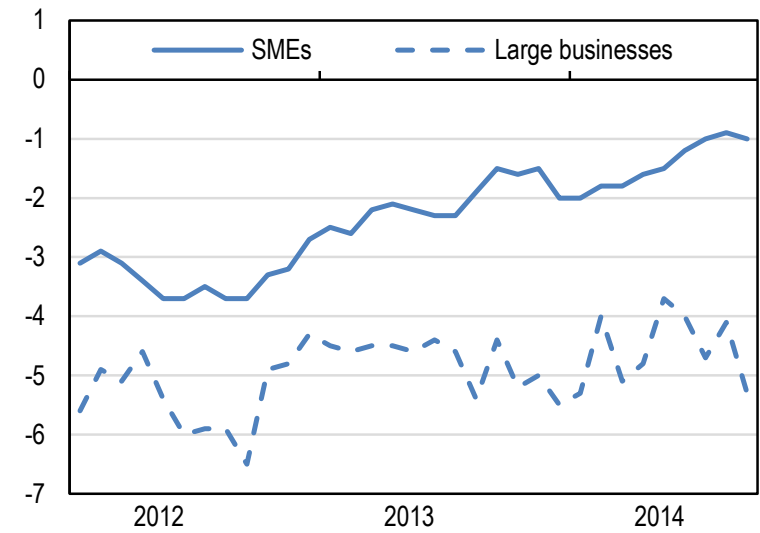

1. 12-month growth rates. Data are not seasonally adjusted.

2. Lending to non-financial corporations (NFCs) refers to UK resident monetary financial institutions' sterling and all foreign currency net lending to NFCs. Lending to households refers to monetary financial institutions' sterling net lending (M4) to the household sector.

3. These data relate to loans and advances in all currencies made by UK monetary financial institutions (MFIs) to non-financial businesses, including to small and medium-sized enterprises (SMEs). SMEs are defined as those with an annual debit account turnover on the main business account of up to GBP 25 million. Those with an annual debit account turnover on the main business account above GBP 25 million are termed "large businesses".

Source: Bank of England (2015), "Monetary and Financial Statistics", Statistical Interactive Database, January.

Figure 4. The bond market has supported the financing of businesses

Net external finance raised by UK businesses, GBP billion ${ }^{1}$

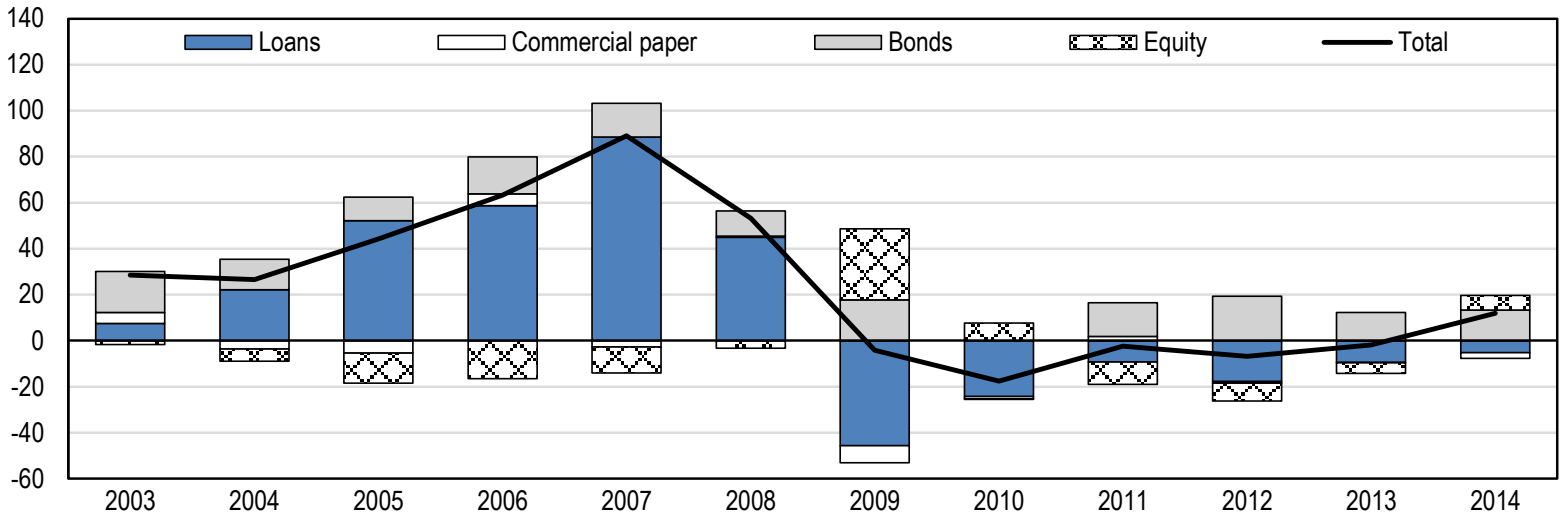

1. Finance raised by private non-financial corporations (PNFCs) UK monetary financial institutions and capital markets. Bonds data cover debt issued by UK companies via UK-based Issuing and Paying Agents. Data are annual and cover funds raised in both sterling and foreign currency, expressed in sterling. Annual data calculated from monthly, non-seasonally adjusted data.

Source: Bank of England (2015), "Monetary and Financial Statistics", Statistical Interactive Database, January. 
At the same time, SMEs do not have meaningful alternatives to bank finance and, in 2012, the United Kingdom (UK) was one of the few countries where outstanding SME loans were lower than in 2007 (Figure 5). In contrast, net lending to households has resumed since 2010, although at a moderate pace (Figure 3). Following the cut in the policy rate to $0.5 \%$ in March 2009, monetary policy has been efficient at reducing the cost of credit: interest rates on bank loans to households and non-financial corporations have declined correspondingly because a large share of lending is done at flexible interest rates (Figure 6, Panel A). However, despite this fall, the spread between interest rates on large and small loans to companies has widened, reflecting a reassessment of risk since the crisis and its underestimation before, and current difficulties for SMEs to get financing (Figure 6, Panel B).

\section{Figure 5. Lending to UK SMEs has not recovered since the crisis}

Change in outstanding loan amounts relative to 2007 , per cent ${ }^{1}$

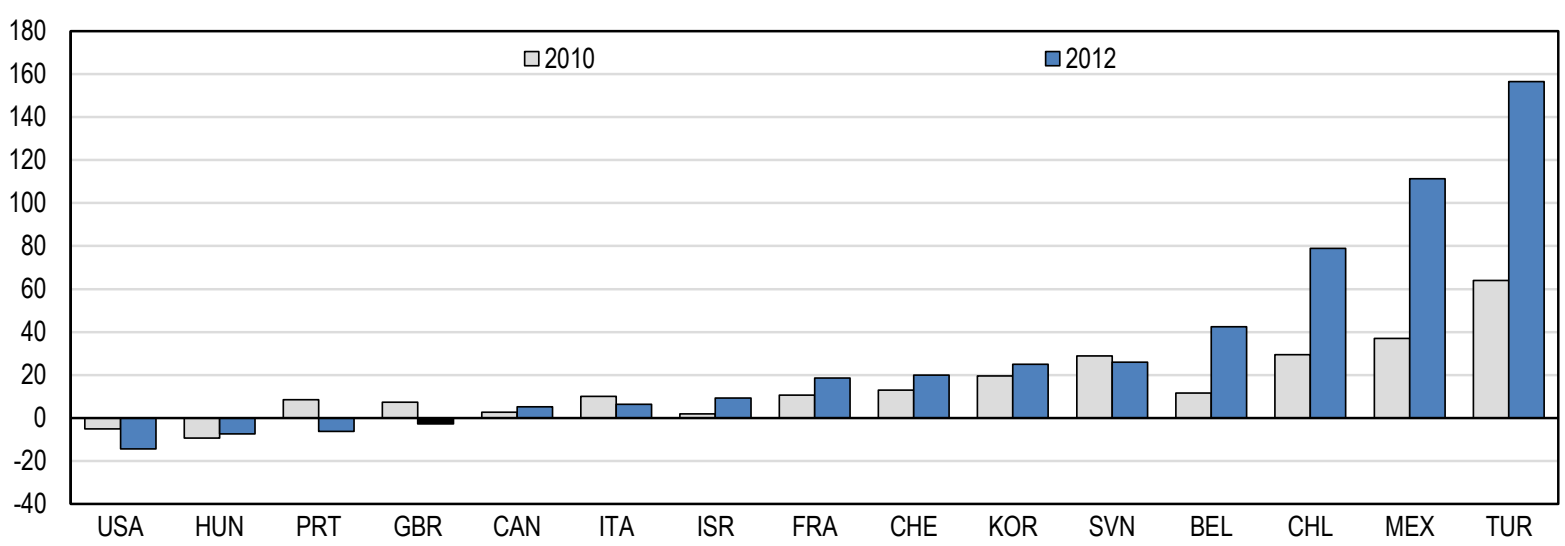

1. Data across countries are not strictly comparable as definitions differ across countries. SME: Small and medium-sized enterprises.

Source: OECD (2014), Financing SMEs and Entrepreneurs 2014: An OECD Scoreboard.

Figure 6. Businesses face lower bank lending rates, but higher risk premiums Percentage points

A. UK interest rates have come down

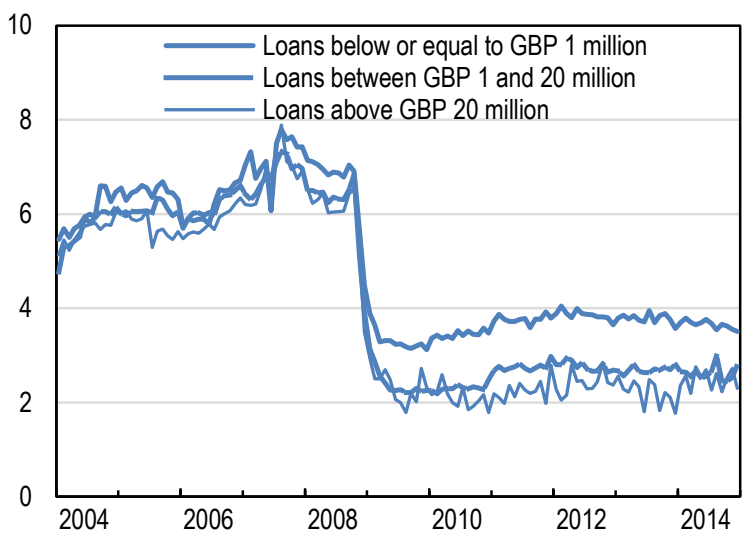

B. Bank lending spreads have picked up Spread between small and large loans ${ }^{2}$

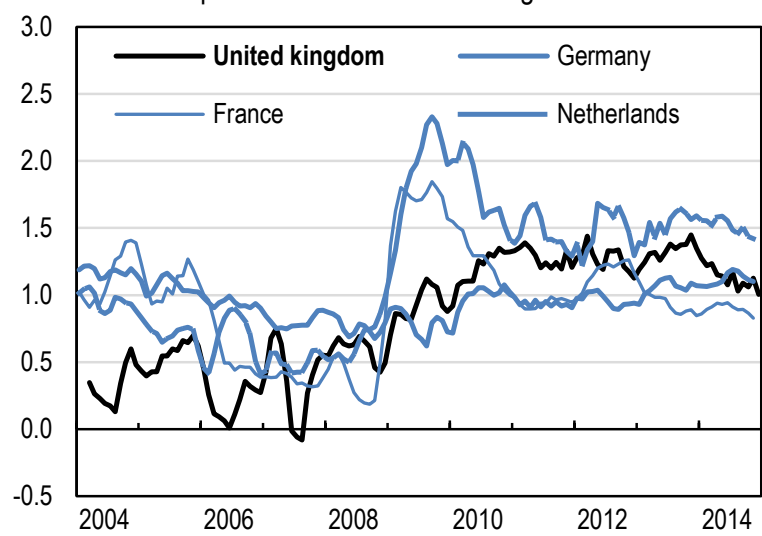

1. Monthly average of weighted average interest rates of UK resident monetary financial institutions' (excluding Central Bank) new sterling loans to private non-financial corporations. Not seasonally adjusted.

2. Three month moving average applied. In the United Kingdom, small loans are defined as loans below GBP 1 million, while in France, Germany and Netherlands small loans are defined as loans below EUR 1 million.

Source: Bank of England (2015), "Interest and Exchange Rates Data", Statistical Interactive Database, January and ECB (2015), "MFI Interest Rates", Statistical Data Warehouse, European Central Bank, January. 


\section{Lending by new credit providers does not substitute for bank financing}

As traditional banks are contracting their lending, new credit providers are entering or strengthening their positions. These include: $i$ ) alternative finance providers (peer-to-peer lending, crowdfunding); ii) institutional investors (such as insurance funds, pension funds, etc.) that provide credit through direct lending funds; and iii) asset-based-finance (factoring, invoice discounting and asset-based lending). Table 1 displays information on direct loan supply by these new credit providers. Transactions by alternative finance providers increased by about $90 \%$ in 2013, but loan amounts are low (Table 1). They explain only $1 \%$ of lending to SMEs and although they start providing a meaningful financing alternative for some businesses, less than 25\% of SMEs are aware of them (CMA and FCA, 2014).

Table 1. Loans provided by monetary financial institutions and new credit providers ${ }^{1}$ GBP billion

\begin{tabular}{|c|c|c|c|c|c|c|}
\hline & 2008 & 2009 & 2010 & 2011 & 2012 & 2013 \\
\hline \multicolumn{7}{|l|}{ Monetary financial institutions } \\
\hline Outstanding loans to NFCs & 503 & 489 & 446 & 421 & 406 & 393 \\
\hline Net lending to NFCs & 13.2 & -21.4 & -11.4 & -12.0 & -10.5 & -2.2 \\
\hline Outstanding loans to households & 1288 & 1301 & 1179 & 1178 & 1184 & 1187 \\
\hline Net lending to households & 66.5 & 22.1 & 11.1 & 9.0 & 7.5 & 15.3 \\
\hline Gross lending to large businesses & .. & .. & .. & 98 & 108 & 120 \\
\hline Gross lending to SMEs & .. & .. & .. & 34 & 38 & 43 \\
\hline \multicolumn{7}{|l|}{ Insurance and pension funds } \\
\hline UK loans holdings at market values & 24 & 22 & 23 & 31 & 34 & .. \\
\hline Net investment in UK loans & 7.3 & -1.7 & 0.7 & 8.1 & 3.0 & 1.2 \\
\hline \multicolumn{7}{|c|}{$\begin{array}{l}\text { Asset based finance: factoring, invoice discounting or } \\
\text { asset based lending }\end{array}$} \\
\hline Outstanding advances & 17 & 13 & 15 & 16 & 16 & 18 \\
\hline \multicolumn{7}{|l|}{ Alternative finance } \\
\hline Finance raised & .. & .. & .. & 0.31 & 0.49 & 0.94 \\
\hline
\end{tabular}

1. New credit providers include donation-based crowdfunding, peer-to-peer fundraising, peer-to-peer lending, peer-to-business lending, invoice trading, equity-based crowdfunding, reward-based crowdfunding, debt-based securities, revenue/profit sharing crowdfunding, microfinance/community shares. NFCs: Non-financial corporations. SMEs: Small and medium-sized enterprises.

Source: Bank of England, Office for National Statistics, Asset Based Finance Association (ABFA) and Collins, L., R. Swart and B. Zwang (2013), "The rise of future finance", The UK Alternative Finance Benchmarking Report.

Alternative finance providers allow direct contact between savers and borrowers. This occurs via social networking based on internet/mobile technology and all financial transaction are web-based. In some cases (donation-based crowdfunding/peer-to-peer online fundraising), no legally binding financial obligation exists between the recipient and the donor. Put differently, no financial or material returns can be expected by the donor. Peer-to-peer or peer-to-business lending platforms allow debt-based transactions between individuals, or individuals and SMEs. Equity-based crowdfunding involves a sale of registered security by mostly early-stage firms to investors.

Alternative forms of finance appear attractive for both individual investors and SMEs. For lenders, interest rates are higher than in banks' savings accounts. For borrowers, procedures seem to be much faster, although interest rates are higher than in banks. Default rates are currently low, but these business 
models have emerged only a few years ago and it is too early to know how they could behave in a downturn. Since April 2014, peer-to-peer lending and crowdfunding have started to be regulated by the Financial Conduct Authority (FCA), which obliges them to have capital buffers against operational risk.

Traditional institutional investors, such as pension funds and insurance companies, form another group of new credit providers, as they started to provide loans through direct lending funds (investment funds which supply credit to enterprises). However, aggregated information about their activities is not readily available. The Office for National Statistics (ONS) documents that holdings of UK loans by insurance and pension funds amounts to nearly $10 \%$ of banks' outstanding loans to non-financial corporations. Unlike lending by traditional banks, net flows have remained positive, albeit volatile, in the wake of the crisis (GBP 1.2 billion or less than $0.1 \%$ of GDP in 2013) (Table 1). Yet, it is not clear what part of this portfolio involves direct lending by institutional investors, securitised loans or loan portfolios bought from banks. Neither the ONS nor the FCA provide information on direct lending by investment trusts. In its annual survey of investment funds, the Investment Management Association does not collect data on direct lending.

Asset-based finance existed before the crisis, and was used exclusively by smaller companies and entrepreneurs. But with tighter access to bank credit, companies of all sizes have been using it since then. Outstanding advances recovered since the crisis and exceeded the pre-crisis peak in 2013 (Table 1). However, low competition and poor corporate governance may have been negatively weighing on access to finance from this source. In 2013, the Asset Based Finance Association introduced the code of conduct, stating six key principles of good practice for anyone providing invoice discounting and factoring services. This was a response to allegations, collected by the group called the Campaign for Regulation of Asset-Based Finance, of excessive fees, unexpected charges and businesses being forced into bankruptcy by their lenders.

\section{Improving access to bank loans and smoothing the credit cycle}

To stimulate nominal demand, the BoE reduced borrowing costs both by sharply cutting interest rates and subsequently embarking on quantitative easing (QE) between March 2009 and October 2012. The Bank bought GBP 375 billion of assets (25\% of GDP), mostly UK government bonds. The implementation of asset purchases was made through the non-bank private sector, notably because of potential concerns that banks would use the proceeds to deleverage had QE been directly implemented through them, rather than to expand lending (Joyce et al., 2011). Still, when assets were purchased from institutional investors, this increased customer deposits and reserves of the banking sector overall, potentially allowing banks to extend more loans. Empirical analysis finds no statistically significant evidence that those banks who received deposits due to quantitative easing lent more (Butt et al., 2014). To help lending more effectively, other policy measures have been implemented with various success, both for companies and households.

\section{Lending to firms have been supported by new policies}

\section{Funding for Lending Scheme has aimed to spur loan supply but with mixed success for firms}

To incentivise loan supply for both households and firms, the BoE and the Treasury launched the Funding for Lending Scheme (FLS) in mid-July 2012, for which both the price and quantity of funding to banks are linked to banks' lending performance. In the initial phase, until January 2014, banks that maintained or expanded their lending benefited from a funding cost of only 25 basis points. One the other hand, banks that contracted their stock of loans saw their cost of funding increased by 25 basis points for every 1 percentage point of contraction in lending, with a maximum fee of 150 basis points. As a result, as long as funding costs were high, banks had an incentive to use the FLS. The introduction of the FLS has contributed to a sustained decline of banks' funding costs (Figure 7), possibly partly owing to quantitative easing and positive spillover effects from receding sovereign debt crisis in the euro area. Over time, this 
made the use of the FLS less attractive. As of end-September 2014, the aggregate FLS drawings amounted to around GBP 49 billion (around 3\% of GDP).

Figure 7. Funding spreads of UK banks have declined

Basis points ${ }^{1}$

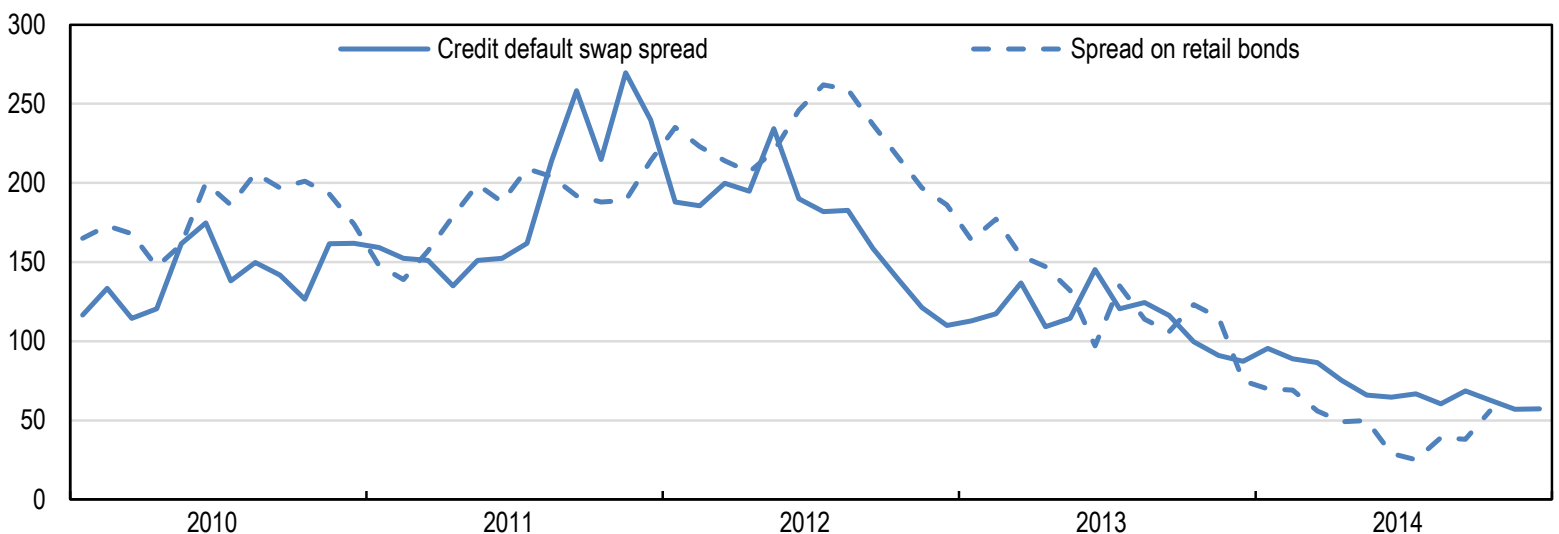

1. Credit default swap (CDS) spread for the UK banking sector refers to five-year senior debt, mid-rate credit default swap CDS spreads. Spread on retail bonds refers to sterling average of two and three-year spreads on retail bonds, over relevant swap rates.

Source: Datastream and Bank of England (2014), "Inflation Report, November 2014".

The programme was very effective for households (see below) but seemingly less effective in supporting lending to companies as net lending to non-financial enterprises has continued to fall. However, the latter declined less so than expected by the BoE prior to the introduction of the FLS and by about what the $\mathrm{BoE}$ expected after its launch (BoE, 2014a). More broadly, corporate credit conditions have improved somewhat since 2012, but the improvement has been more pronounced for large businesses. For example, Credit Conditions Surveys show that credit availability has increased much more for large enterprises than for SMEs (Figure 8, Panel A). Moreover, the SME Finance Monitor suggests that the success rate of obtaining a loan declined in 2013. As a consequence, the design of the FLS was changed in late April 2013 to boost loan supply to SMEs, with banks being allowed to draw GBP 10 of funding for every GBP 1 of net lending to SMEs until December 2013. Empirical evidence using bank-level data has not found an impact on the supply of loans to SMEs corresponding to this expansion of the programme, notably because declining market funding may have reduced banks' incentives to use it (Havrylchyk, 2015). Throughout 2014, banks were allowed to draw a further GBP 5 for every GBP 1 of net lending to SMEs. In November 2014, the programme was extended by an additional year (until January 2016) with an exclusive focus on SME lending, providing an insurance against risks of a sudden increase in banks' funding costs. 
Figure 8. Corporate and household credit availability has been improving until recently

Net percentage balances ${ }^{1}$

\section{A. Corporate credit availability by firm size ${ }^{2}$}

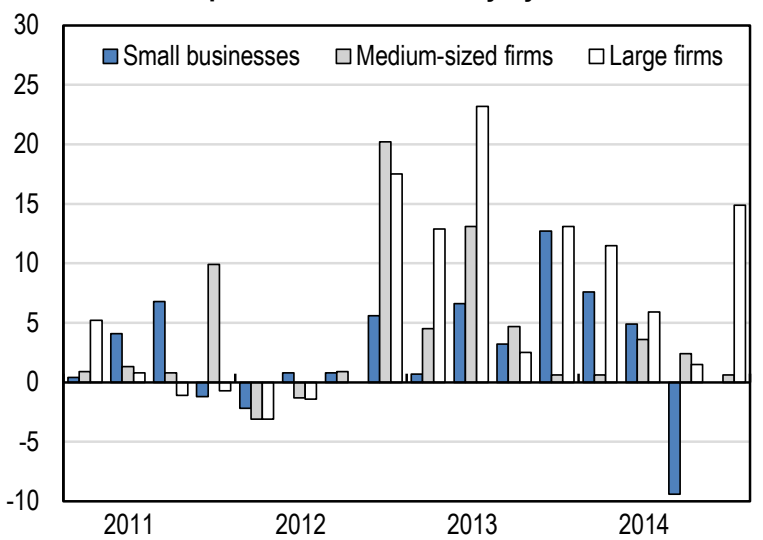

B. Household secured credit availability ${ }^{3}$

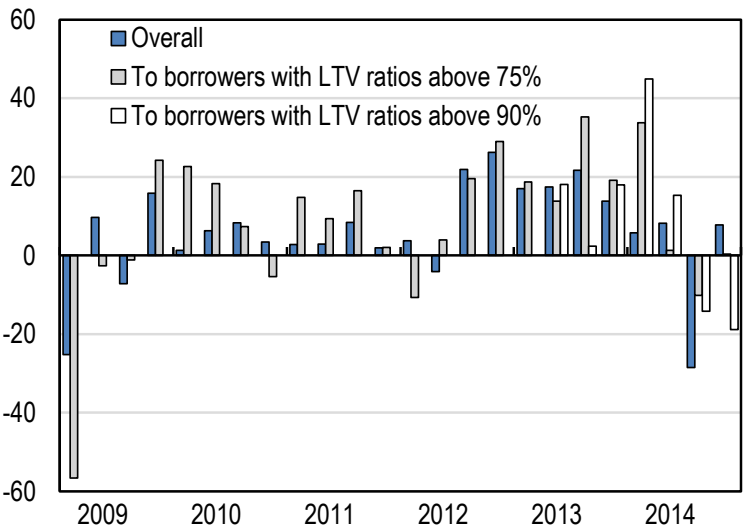

1. A positive balance indicates that lenders, on balance, reported credit availability to be higher than over the previous three-month period. Net percentage balances refer to the difference between the weighted balances of lenders reporting that credit availability was higher/lower. The net percentage balances are scaled to lie between \pm 100 .

2. Small businesses are defined as those with an annual turnover of under GBP 1 million. Medium-sized firms are defined as those with an annual turnover of between GBP 1 million and GBP 25 million. Large firms are defined as those with an annual turnover of more than GBP 25 million.

3. The question on credit availability to borrowers with loan-to-value (LTV) ratios above 90\% was introduced in Q2 2013.

Source: Bank of England (2015), "Credit Conditions Survey 2014 Q4", January.

\section{Public support programmes have been designed to boost SME lending}

The UK government has introduced a number of programmes to spur lending to SMEs (Box 2). All these schemes are united under the roof of the British Business Bank, a commercially-oriented institution. The Bank is expected to become fully operational from 2015. It is not a bank in a conventional sense as it will not finance businesses directly, but it will work with private sector partners by providing funds and guarantees to deliver all of its programmes.

\section{Box 2. Government programmes to support financing of SMEs}

The government has launched a number of initiatives to support the financing of SMEs.

The British Business Bank programmes include:

Business Finance Partnership, first announced in 2011, aims to diversify the sources of finance available to smaller and medium-sized firms with funding of GBP 950 million. One strand of the programme invests in funds which lend to businesses with turnover of up to GBP 500 million. The second strand invests non-traditional channels that provide an alternative source of finance (peer-to-peer, supply chain finance, asset finance lenders and mezzanine finance providers) for small businesses with turnover up to GBP 75 million. Around GBP 860 million has been allocated for supporting medium-sized firms, with GBP 260 million invested alongside private money, generating slightly over GBP 800 million of lending to businesses in the year to end-September 2014.

Enterprise Finance Guarantee $(E F G)$ enables lenders to provide debt finance to small businesses with insufficient collateral or track record. The EFG supported close to GBP 350 million of lending in 2013-14, up by about $20 \%$ on the previous financial year, helping 3000 businesses.

Enterprise Capital Funds make equity investments in early stage companies. Nearly GBP 290 million of public money has been invested in 14 funds, alongside GBP 200 million from private investors. About 160 businesses have received investment so far. 


\section{Government programmes to support financing of SMEs (cont.)}

Venture Capital Catalyst Fund is a new variant to the existing Enterprise Capital Fund programme, co-investing on the same terms as private investors. It has a funding capacity of up to GBP 125 million and makes investments of GBP 5-10 million in private sector-led venture capital funds.

Business Angel Co-Fund supports angel investments in innovative start-ups. The fund has supported almost 30 businesses since its launch in November 2011.

Start-Up Loans scheme was established in 2012 to provide mentoring and financial support to young entrepreneurs, and saw the available funding doubled to around GBP 320 million following the Autumn Statement 2013. Over 23000 loans totalling more than GBP 125 million have been made since the launch in April 2012.

In addition to the British Business Bank programmes, several schemes have been created and supported by tax reliefs to incentivise investment into small and growing businesses:

Seed Enterprise Investment Scheme (SEIS) was launched in April 2012 to support start-ups, and made permanent in Budget 2014. SEIS offers 50\% income tax relief on investments made into qualifying small, early-stage companies and some associated capital gains tax exemptions. Over 2000 companies have raised over GBP 175 million of SEIS investment since the scheme was introduced in 2012.

Enterprise Investment Scheme and Venture Capital Trust, respectively introduced in 1994 and 1995 and in force since then, aim at helping smaller higher-risk trading companies by offering a range of tax reliefs to investors who purchase new shares in those companies.

Over the next five years, the Bank aims to unlock up to GBP 10 billion of financing for viable smaller businesses bringing public resources to $0.6 \%$ of GDP. This will make the UK public support program to SMEs close in size to similar programmes in France, Italy and Germany (Infelise, 2014). The British Business Bank should continue to address market failures in access to finance for projects with high economic potential by assessing SME finance markets to identify any new areas for intervention and evaluating the impact of its existing programmes. The authorities should consider transforming the British Business Bank into a permanent instrument of SME financing, beyond the current framework allowing the Bank to reinvest the returns of its programmes.

The main difference between the British Business Bank and its peers in other countries, such as France or Germany, is that the British Business Bank will not provide loans directly to SMEs, but rather to smaller banks and alternative finance providers that specialise in SME finance. Supporting lending through alternative finance providers is an innovative but untested feature. Although they face lower operating costs than banks, their interest rates could exceed rates charged by large banks, which benefit from deposit insurance and implicit government guarantees. In contrast, the German Kreditanstalt für Wiederaufbau (KfW) is able to provide loans to SMEs on attractive interest rates owing to government guarantees of its bond issuance, zero tax rate and zero dividends due to state ownership.

The introduction of government schemes should relieve credit constraints of SMEs, in particular in the short term (OECD, 2014; Öztürk and Mrkaic, 2014). However, it is necessary to perform a regular assessment of these programmes and to review them, if needed. For example, government incentives to lend to SMEs in Japan in the 1990s led to higher non-performing loans (Hoshi and Kashyap, 2010). There is also a need to evaluate the extent to which net lending is larger as a result of public intervention and not due to displacement of other sources of lending. This will require to improve data availability, in particular at the firm level and including credit statistics on credit conditions, collateral, purpose of credit, etc. (OECD, 2014). 


\section{The SME bank credit market is not competitive}

The SME bank credit market is highly concentrated, which is likely to create a structural barrier to access to finance: $90 \%$ of the SME credit market is controlled by three banks in Scotland and by four banks in England, Wales and Northern Ireland. New entrants have difficulties in obtaining information on the creditworthiness of prospective borrowers (CMA and FCA, 2014; Large, 2013). The fact that some of these major providers of SME credit experienced large financial difficulties during the crisis and needed to restructure their activities has hurt the SME sector. It is possible that if the provision of credit had been more diversified, the credit constraints would have been less tight.

Market concentration has increased significantly during the crisis due to the merger of Lloyds TSB and HBOS in 2009. This happened despite concerns of the Office of Fair Trade (OFT) that a new merger would lessen the competition, notably in the markets for banking services to SMEs (Smith, 2008). Normally a merger of this size and scale would have required to be referred by the OFT for clearance of the Competition Commission, but the government had waived such investigation as ensuring the stability of the UK financial system outweighed competition concerns.

The contestability of the SME bank lending market is poor, which leads to low satisfaction and increases the cost of banking services for businesses. Still, banks with lower customer satisfaction levels have high market shares and are not losing them, while those with the highest customer satisfaction are not able to expand. Although $10 \%$ to $20 \%$ of SMEs rate the overall standard of service received from their main bank as poor, the switching rate is less than 5\% and has been unchanged for a decade. More SMEs would be unwilling to recommend a large bank to a friend than would be willing to do so; the opposite is true for smaller banks. The analysis of the Competition and Markets Authority (CMA) and FCA (2014) and the Independent Commission on Banking (ICB) (2011) also found that smaller banks were around $15 \%$ to $30 \%$ cheaper than large banks and differences are likely to be even larger for loan pricing, which is difficult to compare across banks.

Recent measures have aimed to incentivise customers to switch banks and they need to be continued. Since September 2013, the Current Account Switch Service has been put in place, following the recommendation of the ICB (2011). It allows SMEs with a turnover of up to EUR 2 million (or sterling equivalent) to have a simplified procedure to switch a bank. This should lower switching costs and encourage mobility and competition. This service has increased the rate of account switching, but it is too early to assess whether this is a structural change or a temporary uptick driven by advertising. An additional step forward would be to lower switching costs for SMEs with existing loans, as this is not addressed by the above service.

\section{More credit data sharing would enhance loan provision to SMEs}

Beyond lowering switching costs, additional measures are needed to spur competition and strengthen credit availability by reducing informational asymmetries between incumbent and new banks about customer creditworthiness. The situation of "hold-up" by incumbent banks creates a barrier to the entry and expansion of smaller and newer credit providers and could lead to higher prices, less lending and higher defaults than it would be the case in a perfectly competitive market.

A well-functioning credit information sharing scheme could reduce informational asymmetries and has been shown to lower the cost of intermediation and to improve access to credit (Brown et al., 2009). In the UK, credit data are shared by banks through credit reference agencies (CRAs). However, some banks do not provide comprehensive data on their clients and hence have more information on their customers. Moreover, the data is provided on the principle of the reciprocity, so for example, business current account data can only be accessed by providers of business current account data, which excludes new credit providers. 
To address the issue of data sharing, the government has launched three initiatives. In 2014, it proposed to make mandatory the supply of SME data (positive and negative) to CRA and its sharing between lenders (including some new credit providers) through CRAs. Moreover, to improve information on regional and local lending, the government agreed in 2013 with major banks that they will publish lending data across nearly 10000 postcodes. This should allow new lenders (banks and new credit providers) to identify areas of unmet demand, hence promoting greater competition. Finally, following a consultation the government plans to require banks to refer details of SMEs that have been rejected for loans to smaller banks and other providers of finance.

Information sharing could be further improved in line with the recent proposals of the $\mathrm{BoE}(2014 \mathrm{c})$. To enhance competition, credit information collected by the CRAs should be shared, in appropriate form, with all non-direct lenders, including trade credit providers and investors in securitised credit. Furthermore, banks should be able to have access to pooled data, which would provide a level playing field for small and large banks when setting risk weights. Risk weights are about $60 \%$ higher under the standardised approach used by small banks, than under internal risk-based approach which is derived from a model and is used by large banks (Le Leslé and Avramova, 2012). Allowing access to CRA data by small banks would help them to switch to the internal risk-based approach that requires long-term data on a large number of borrowers to build risk models.

Another welcome measure would be to allow the BoE to have access to CRA data, which is important from the perspective of macro-prudential and monetary policies. Alternatively, the authorities could consider establishing a central credit registry, as has recently been proposed (BoE, 2014b). Creating a business register would also be beneficial to uniquely identify a business and match information from different data sources. This would further reduce informational asymmetries about borrowers' creditworthiness and be an additional step forward to improve credit availability.

\section{Lending support to households has contributed to housing market recovery}

The introduction of the FLS coincided with a pickup in net lending growth and larger credit availability to households (Figure 3, Panel A and Figure 8, Panel B). It is probable that the FLS helped to reduce bank funding costs and boosted household lending. The BoE finds the latter by comparing current credit developments with a counterfactual credit development if the FLS had not been introduced (BoE, 2014a). In late November 2013, the FLS programme for household lending was discontinued.

\section{Help to Buy programme has further relaxed credit conditions}

In March 2013, the government announced the Help to Buy programme to boost the housing market (Box 3). The programme consists of two key schemes: the government provides either a mortgage guarantee to the lender or an equity loan to the borrower for the amount of $20 \%$ of the price of a dwelling. Both schemes allow households to take out a mortgage with 95\% loan-to-value (LTV) ratio to buy a house with a purchase price up to GBP 600 000. Equity loans are available for newly built dwellings (until 2020), while government guarantees apply to existing and new homes (until the end of 2016). 


\section{Box 3. Help to Buy programme}

In March 2013, the government announced the Help to Buy programme. It has two elements: equity loans and mortgage guarantees. The equity loan scheme was implemented in April 2013, while the mortgage guarantee scheme started in October 2013. The government also maintained a NewBuy scheme that was launched in March 2012.

\section{Equity loans}

The equity loan scheme is open to both first-time buyers and home movers for new dwellings in England with a purchase price up to GBP 600000 . The property cannot be sub-let and it must be the only property of the borrower. With an equity loan, the borrower has to contribute at least $5 \%$ of the property price as a deposit, the government provides a loan for up to $20 \%$ of the price and the rest of $75 \%$ is covered by a mortgage. The equity loan is interest free for the first five years. After that, the borrower pays a fee of $1.75 \%$, rising annually by the increase (if any) in the Retail Price Index plus 1\%. The loan must be repaid after 25 years or when the borrower sells his or her home whichever is earliest. The amount of repayment depends on the market value of the property at the time of repayment (Table 2).

Table 2. Equity loan scheme of Help to Buy: an example

\begin{tabular}{ccc}
\hline $\begin{array}{c}\text { Market value of home } \\
\text { (GBP) }\end{array}$ & $\begin{array}{c}\text { Equity loan taken out } \\
(\%)\end{array}$ & $\begin{array}{c}\text { Amount of equity loan } \\
\text { (GBP) }\end{array}$ \\
\hline Bought for 200000 & 20 & Borrowed 40000 \\
Sold for 250000 & 20 & Pay back 50000 \\
Sold for 150000 & 20 & Pay back 30000 \\
\hline
\end{tabular}

\section{Mortgage guarantees}

The mortgage guarantee scheme helps to buy a home with a deposit of $5 \%$ of the purchase price. It is open to both first-time buyers and homeowners for new and existing dwellings in the United Kingdom with a purchase price up to GBP 600000 . The guarantee is provided to a mortgage lender, not to the borrower. To qualify, the home must not be a shared ownership or shared equity purchase, not be a second home and not be sub-rented.

\section{NewBuy}

NewBuy lets the borrower buy a newly built home with a deposit of only $5 \%$ of the purchase price. To be eligible for NewBuy, the new home must be priced at GBP 500000 or less, be the main home of the borrower, be fully owned by the borrower and built by a builder taking part in the scheme. Developers put $3.5 \%$ of the value of eligible home sold to an indemnity fund to protect the lender in the case of default, with the government guaranteeing a further $5.5 \%$ of the sales price if the fund is emptied. The borrower does not have to be a first-time buyer and there is no limit on the level of income.

The use of the Help to Buy programme has so far been consistent with the authorities' plans. There were almost 38000 completions for equity loans as of the end of November 2014 and around 30000 completions for the mortgage guarantee scheme by the end of September 2014, representing together around 3\% of all mortgage approvals for house purchase during the last 19 months until September 2014.

Although Help to Buy has not spurred lending, it may have had strong effects on the housing market. The introduction of the programme has coincided with greater credit availability (Figure 8, Panel B) and the weakening of some underwriting standards (Figure 9). The share of loans with loan-to-income (LTI) ratios above 4 is higher than before the crisis and the amount of loans with LTV ratios above $95 \%$ trebled over the year to May 2014 (BoE, 2014c). Many lenders attributed this to participation in Help to Buy programme (BoE, 2014c). The price cap for eligibility has been set significantly above average house prices, including in London, which may have stimulated house price expectations. In October 2014, the BoE's Financial Policy Committee requested new powers from the government to cap loan-to-value and 
debt-to-income ratios for mortgages (see below), but also assessed that the mortgage guarantee scheme did not pose material risks to financial stability and was not a material driver of house price growth.

Figure 9. Underwriting standards developments have been mixed

Per cent ${ }^{1}$

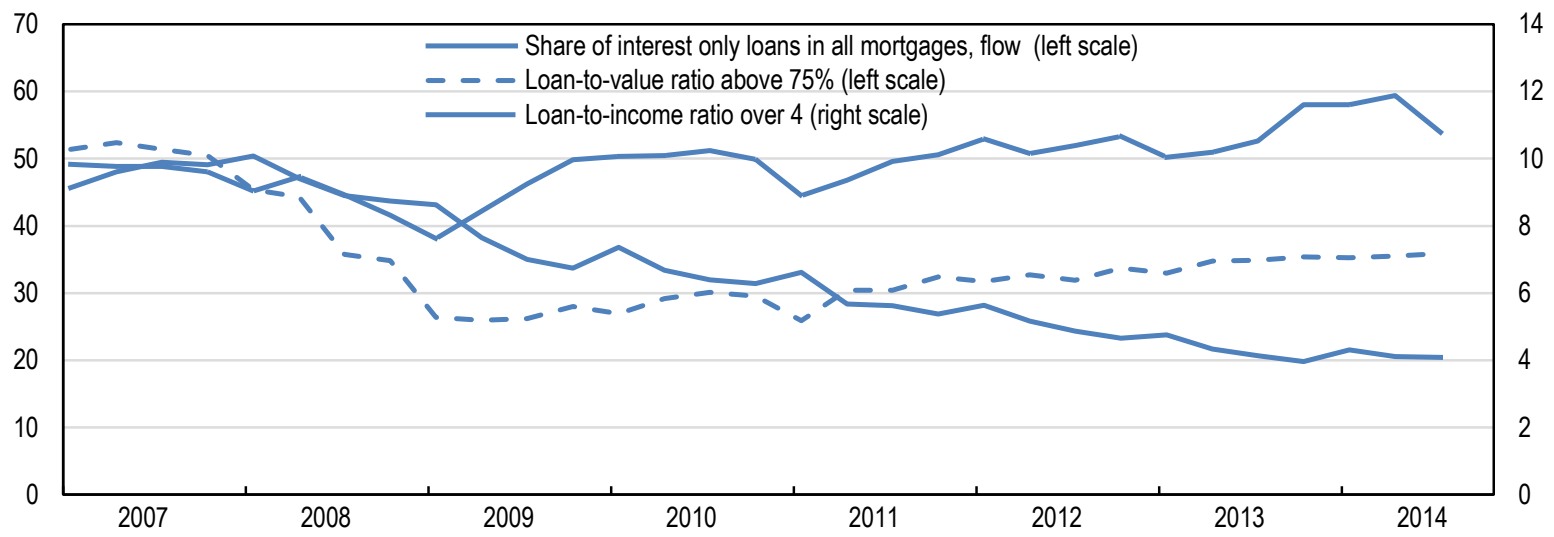

1. Share of interest only loans in all (i.e. regulated and non-regulated) mortgages to individuals.

Source: Bank of England (2014), "Mortgage Lenders and Administrators Statistics - 2014 Q3 ", Prudential Regulation Authority, December.

The equity loan scheme has an interesting feature. It shares the house price risk between the government and households by linking the amount of repayment to the price of the house. This limits the risk of negative equity when house prices fall, but also reduces capital gains when house prices rise (Box 3). This is similar to a recent proposal of Mian and Sufi (2014) to render household financing more equity-like, with equity participation taken by the private lender. In contrast, in Help to Buy loan equity scheme this participation is taken by the government. The taxpayer could be better able to bear house price risks, but its exposure to negative shocks has increased as house prices look increasingly overvalued based on simple indicators (Figure 10).

Figure 10. House prices have been buoyant and are high relative to incomes and rents

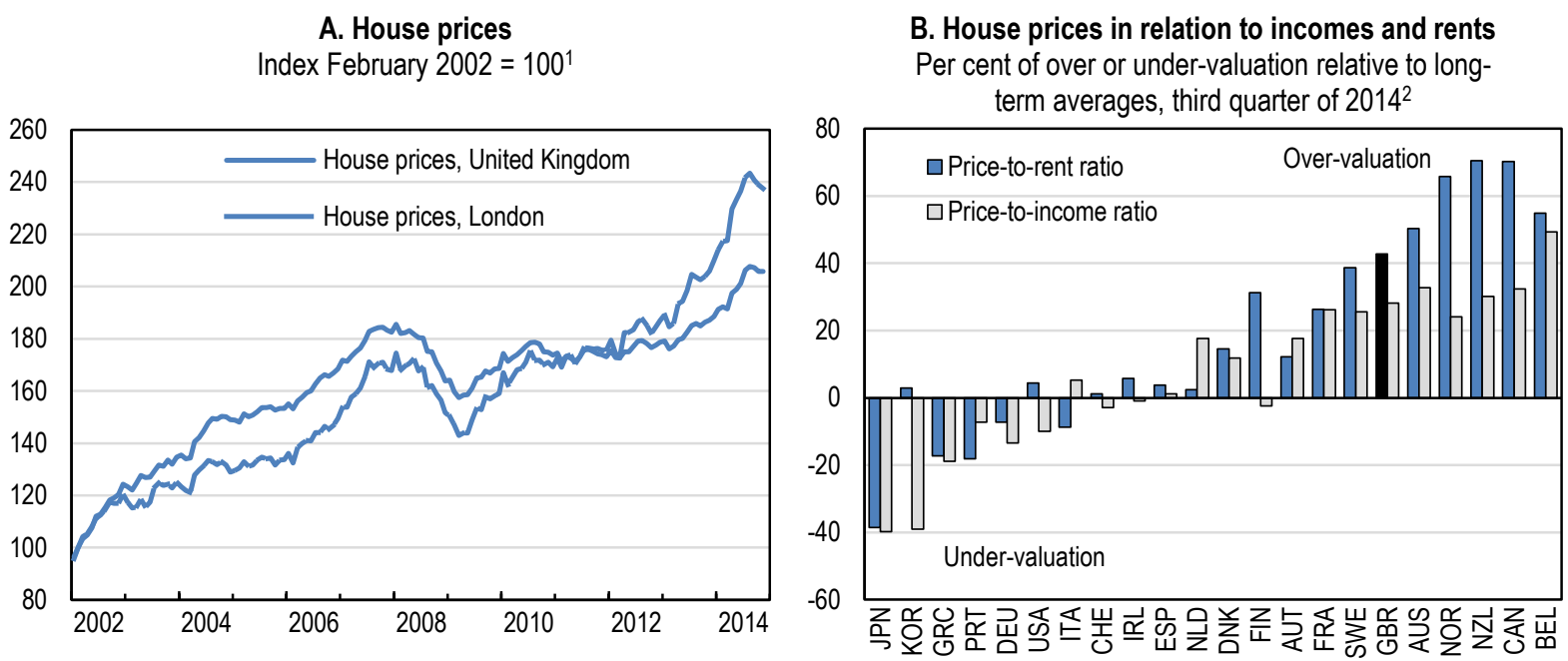

1. Nominal house prices.

2. Second quarter of 2014 for Italy and New Zealand. Countries are ranked by the average of the two indicators, from lowest to highest. The long-term average covers the period from 1980 (or earliest available date) to the latest available quarter.

Source: ONS (2015), "House Price Index, December 2014", Office for National Statistics, February and OECD (2015), OECD Housing Prices Database, Economics Department, February. 
Beyond improving access to finance for households, providing affordable dwellings requires making housing supply more responsive. Further efforts are needed to relax regulatory constraints imposed by the planning system. As discussed in the previous Surveys, it is essential to make some protected lands available for building houses and to ease skyline restrictions in some cases (OECD, 2011, 2013a). In particular, reviewing the boundaries of the Green Belt - introduced in 1955 to prevent urban sprawl around historical towns and cities on close to $12.5 \%$ of England - would free up land for development. Additional structural reforms would help to balance the housing market (OECD, 2011; André, 2011). Higher provision of social housing could enhance housing supply where private sector activity is insufficient, while updating property valuation of the council tax would damp large swings in house prices. The government has announced a reform of the residential stamp duty land tax, which should lower transactions costs on most properties and encourage labour mobility, but may also create upward pressure on house prices in the short term (OBR, 2014).

\section{Macro-prudential regulation should prevent imbalances and help smooth the credit cycle}

Although government programmes are important to support short-run loan supply, in the long run macro-prudential policy should sustain the resilience of the financial system by preventing the build-up of imbalances, such as excessively volatile credit growth (Figure 11). In line with this objective, the BoE has obtained a responsibility for financial stability with a number of powers and macro-prudential tools, which are complemented by its powers over monetary policy and micro-prudential supervision (Box 4). Strong accountability and transparency are necessary about decision-making, supported by robust communication (IMF, 2014a). In this respect, joint meetings of the Financial Policy Committee (FPC) and the Monetary Policy Committee (MPC) are welcome to ensure smooth co-ordination between monetary and macro-prudential policies (Shakir and Tong, 2014). Current internal reform of the BoE to ensure a better flow of information and centralisation of multiple data sources collected separately by different departments is also a step in the right direction.

Figure 11. UK credit to GDP ratio has been volatile ${ }^{1}$

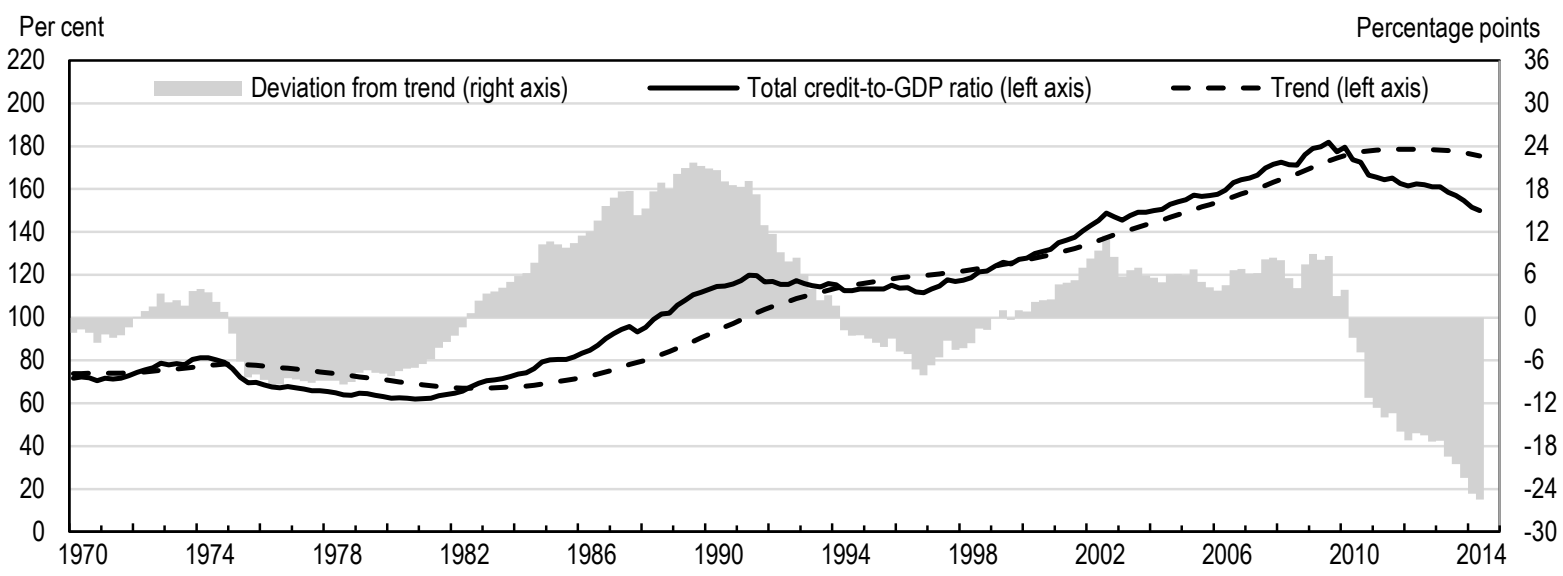

1. Credit is defined as debt claims on the UK private non-financial sector. This includes all liabilities of the household and not-forprofit sector and private non-financial corporations' (PNFCs) loans and debt securities excluding derivatives, direct investment loans and loans secured on dwellings. Long-term trend of credit-to-GDP ratio is based on a one-sided Hodrick-Prescott filter with a smoothing parameter of 400000 .

Source: Bank of England (2014), "Financial Stability Report, December 2014", Issue No. 36, December. 


\section{Box 4. Recent reforms of the supervisory framework}

In the wake of the crisis, the institutional structure of the UK financial regulation and supervision has been revamped by the Financial Services Act, which came in force in April 2013. The Act discontinued the Financial Services Authority and has expanded the responsibilities of the Bank of England (BoE) with regards to financial stability, which rests on three pillars.

The Prudential Regulatory Authority (PRA) is responsible for the prudential regulation and supervision of banks, building societies, credit unions, insurers and major investment firms.

The Financial Policy Committee (FPC) is in charge of taking action to reduce systemic risks with a view to protecting and enhancing the resilience of the UK financial system. It can make recommendations on the "comply or explain" basis to the PRA and the FCA, and so far most of these recommendations have been made to the PRA. Moreover, the FPC can impose specific macro-prudential tools, such as sectoral capital requirements and countercyclical capital buffers. The FPC can adjust sectoral capital requirements for banks' exposures to three broad sectors (residential property, including mortgages; commercial property; and other parts of the financial sector), as well as more granular subsectors (for example, to mortgages with high loan-to-value or loan-to-income ratios at origination). In its 2014 policy statement, the FPC explains conditions under which these tools might be activated (FPC, 2014).

Finally, the Resolution Directorate within the BoE is responsible for planning and implementing resolutions of failing UK banks and building societies.

In addition, the Financial Services Act established an independent Financial Conduct Authority (FCA) to ensure consumer protection and to promote effective competition in the interest of consumers. Hence, the FCA is responsible for the conduct supervision of all regulated financial firms and the prudential supervision of those not supervised by the PRA.

\section{Risks in the housing market are being addressed with macro-prudential tools}

With rapid increases in house prices over the recent past and signs of overvaluation (Figure 10), housing market developments have been identified as the largest risk to financial stability by the FPC (BoE, 2014c). At the same time, accommodative monetary policy needed to support economic activity may also increase risk-taking by banks while loans issued during periods of low interest rates become impaired more often once interest rates rise (Jiménez et al., 2014). Hence, while very low interest rates reduce interest payments and create conditions for declines in household indebtedness, macro-prudential tools should head off risks of a credit boom driven by households becoming even more indebted. Further progress in deleveraging would reduce household exposure to interest rate hikes and smooth consumption, as it has recently been assessed that $60 \%$ of borrowers would cut spending in response to a hike in the policy rate to $2 \%$ (Anderson et al., 2014).

Regulatory authorities have been taking appropriate action to prevent a further deterioration in underwriting standards and an increase in highly indebted households. In April 2014, the FCA took action following a review of the mortgage market with a view to encourage stricter affordability checks, stresstesting, mortgage advice and to prevent self-certification mortgages. In June 2014, the FPC and the Prudential Regulatory Authority (PRA) enforced the need for all banks to decline loans to borrowers who fail to withstand a 3 percentage-point increase in the benchmark rate over the first five years of the loan. The FPC also introduced a limit of the proportion of mortgages at 4.5 times income to no more than $15 \%$ of banks' new home loans. In parallel, the government decided that all mortgages taken out under the mortgage guarantee scheme of Help to Buy will be capped at 4.5 times income. The percentage of mortgages greater than 4.5 times income was close to $10 \%$ across the country, although it reached nearly $20 \%$ in London in 2013. The introduction of some of these measures was followed by a tightening of credit availability indicators for households in the third quarter of 2014 (Figure 8, Panel B).

The BoE's approach to introduce macro-prudential gradually is appropriate, but it should stand ready to undertake new steps if vulnerabilities persist. The authorities could lower the $15 \%$ ceiling for loans with 
high income multiple and/or to broaden coverage to more types of loans or lenders (for example by including buy-to-let properties) (IMF, 2014a). In October 2014, the FPC requested from the government new regulatory powers to strengthen financial stability by capping LTV ratios and debt-to-income (DTI) ratios for residential mortgage lending (owner-occupied and buy-to-let). This is a welcome step as caps on high DTI and LTV ratios appear effective in reducing mortgage credit growth and/or house price inflation and the effectiveness of macro-prudential policies is maximised when several tools are used simultaneously (IMF, 2014a; Claessents et al. 2013; Kuttner and Shim, 2013). More generally, macro-prudential policies appear to be better suited than monetary policy to tackle property prices imbalances, with monetary policy being the last line of defence if macro-prudential tools prove to be insufficient (Crowe at al., 2011).

\section{Activating countercyclical capital requirements}

Countercyclical capital requirements should be based both on a range of indicators and judgment. Such multifaceted approach is currently being developed, which is welcome and should be continued. Exclusive reliance on discretion in decision-making could lead to time-inconsistency problems (Crowe et al., 2011; Haldane, 2013). History suggests that attitudes towards risk change over time and are subject to myopia, and periods before crisis are characterised by "irrational exuberance" and the belief that "this time is different" (Reinhart and Rogoff, 2009). This phenomenon is particularly important because credit cycles are much longer than business cycles (Haldane, 2010; Haldane, 2014). Models and indicators cannot be applied mechanically or automatically and ultimately it is the key task of the FPC to make a judgement based on all available information.

Pro-cyclicality and systemic risk could also be mitigated when setting risk weights. Banks' annual reports show that risk weights are very low for government bonds (less than 10\%) and retail mortgages (around 15\%), but higher for business loans (around 40\%) and particularly high for SME lending (around $60 \%$ ). Hence, lending to SMEs appears to be much more costly in terms of capital requirements than lending to households. Although these weights reflect higher probabilities of SME failure, they may not take sufficient account of systemic risk associated with household or government debt. For example, UK risk weights are indexed to LTV ratios. Therefore, they decline for existing mortgages during property booms, contributing to the pro-cyclicality of the financial sector.

\section{Addressing interest-only mortgages}

The repayment of interest-only mortgages (principal redemption is postponed to the maturity of the loan) is a concern. Although their flow has declined substantially to about $20 \%$ of total (Figure 9), the total stock still accounted for almost 40\% of the UK's total balances in 2014 (according to the Mortgage Lenders and Administrators statistics of the Bank of England). Buy-to-let interest-only mortgages, which account for half of the flow and a third of the stock, could represent a lower risk for financial stability for loans with low LTV ratios. In May 2014, the FCA concluded that 600000 borrowers will see their mortgage mature before 2020. Around $10 \%$ had no plan to repay their debts, just under half will face potential repayment shortfalls that may reach over GBP 50000 in a third of cases (GfK, 2013; FCA, 2013). Over the next 30 years, 2.6 million interest-only mortgages will fall due and $10 \%$ of borrowers do not have a strategy to repay their loan. Banks were required to contact borrowers whose mortgage will be due before 2020 and, more recently, lenders have been asked to check repayment plans of borrowers for the full loan instead of relying on increased house prices as the only plan for principal reimbursement. These are welcome steps and should be continued. Additionally, increasing risk weights on interest-only loans would increase capital buffers against future credit risk and prevent a weakening of underwriting standards should the risk appetite for such loans increase. 


\section{Reducing risks posed by the financing system via sound regulation}

\section{The large size of UK banks poses a risk}

\section{Market pressure on rewarding higher capital ratios could be waning}

Before the crisis, banks' funding was not priced in accordance with their level of risk. Due to implicit government guarantees and under-pricing of risk, global systemic banks with lower leverage ratios had the same cost of funding as well-capitalised global systemic banks (Figure 12, Panel A). This has changed in the wake of the crisis as markets have started to price risk better and the relationship between the risk premium on external funding and bank capital has become more dispersed (Figure 12, Panels B and C). However, recent data shows that with low spreads and low risk aversion this relationship is flattening again (Figure 12, Panel D). Although lower average spreads reduce the cost of financial intermediation, it is important that markets exert discipline on banks that are poorly capitalised, inefficient, or excessively risky, and charge them higher risk premiums on debt. This could be achieved by continuing to enforce tighter regulatory capital requirements and further strengthening banks' resolvability.

Figure 12. Relationship between leverage ratio and funding costs of global systemic banks ${ }^{1}$

A. End of 2005

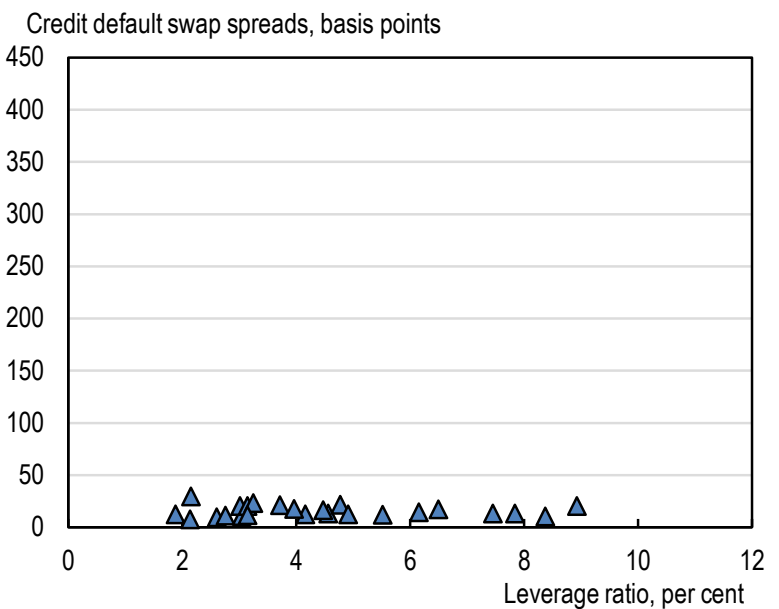

C. End of 2011

Credit default swap spreads, basis points

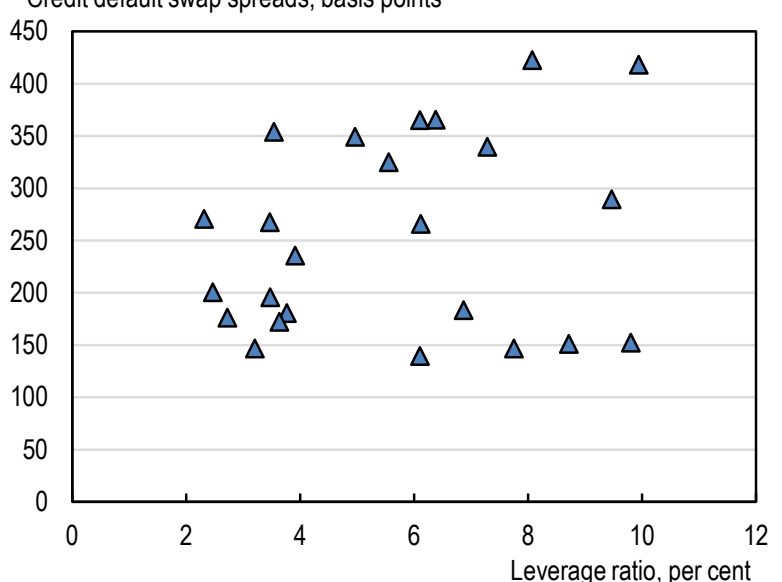

B. End of 2008

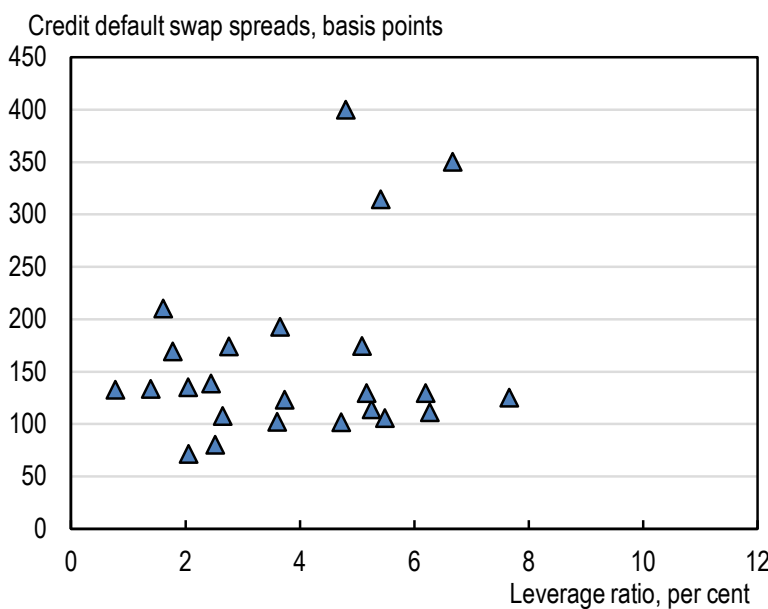

D. End of 2013

Credit default swap spreads, basis points

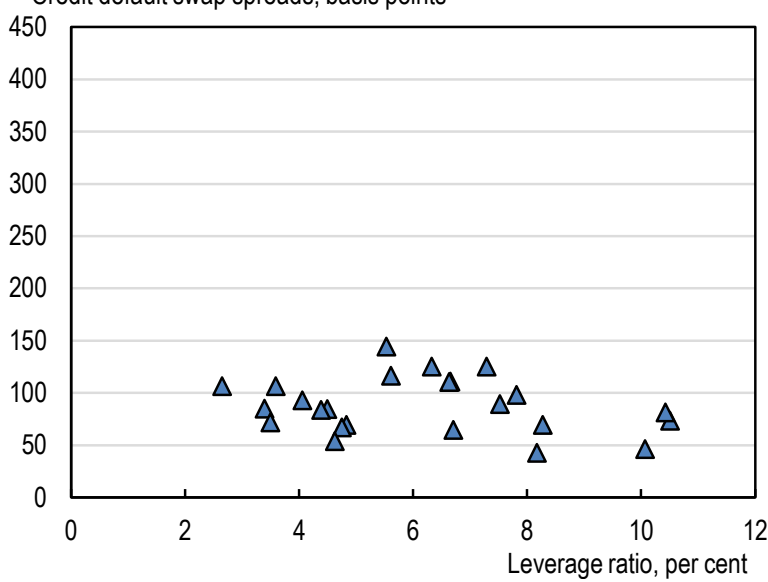

1. Data refer to 24 out of the 29 global systematically important banks (G-SIBs) as defined by the Financial Stability board. Credit default swap (CDS) refers to five-year senior debt, mid-rate spreads. Leverage ratio refers to the share of total common equity in total assets.

Source: Datastream and Bloomberg. 
Despite important reforms the problem of systemic banks remains

The assets of the two largest UK banks amounted to about 180\% of GDP in 2013, against almost $160 \%$ of GDP in 2007 (Figure 13). A lack of market pressure to reward higher capital ratios for systemically important banks could pose risks as the UK banking sector is still dominated by big banks. The UK banking sector is deleveraging as measured by total banks' assets and loans (Figure 14). This is consistent with other large banking industries before the crisis, and which have been reduced afterwards such as in Switzerland, Ireland and Belgium. The situation varies between individual banks, as banks that had received government support have been selling their non-core assets, while other banks have significantly increased their asset size.

\section{Figure 13. Size of two major banks remains large}

Total assets, per cent of GDP ${ }^{1}$

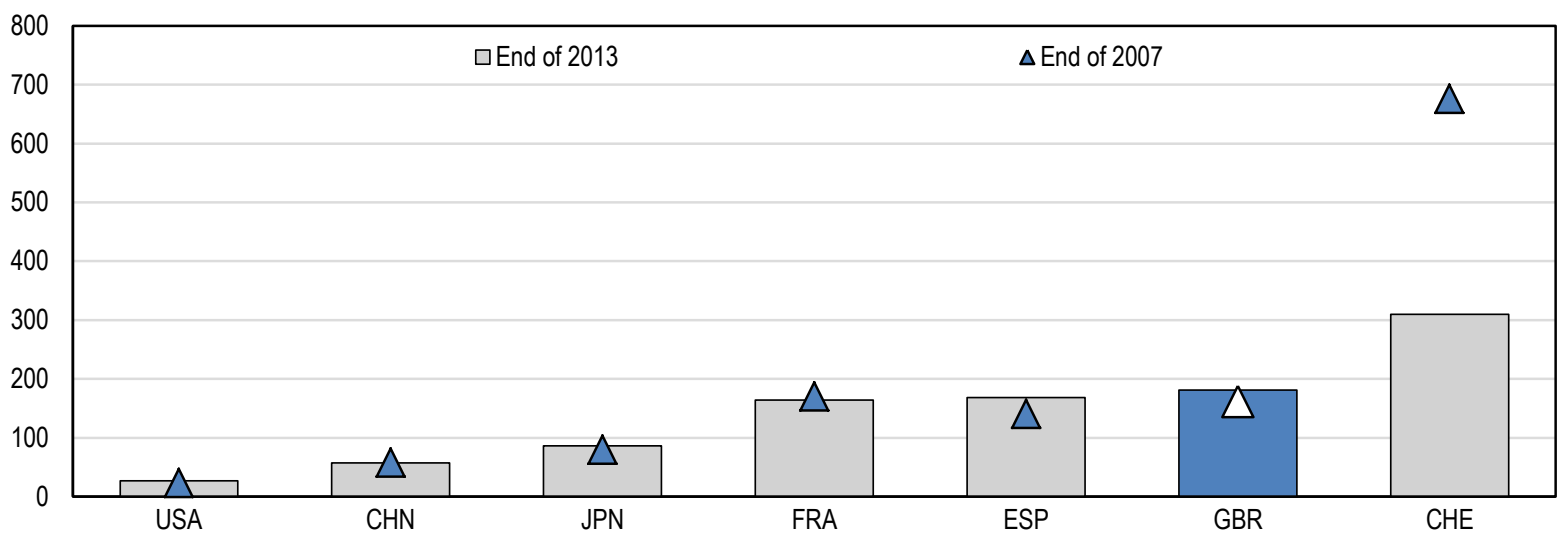

1. Total assets refer to the sum of cash and bank balances, Fed funds sold and resale agreements, investments for trade and sale, net loans, investments held to maturity, net fixed assets, other assets, customers' acceptances and liabilities.

Source: Bloomberg and OECD (2015), OECD National Accounts Statistics (database), January.

Figure 14. UK banks are deleveraging their total assets and loans

Per cent of GDP

A. Total assets of banks

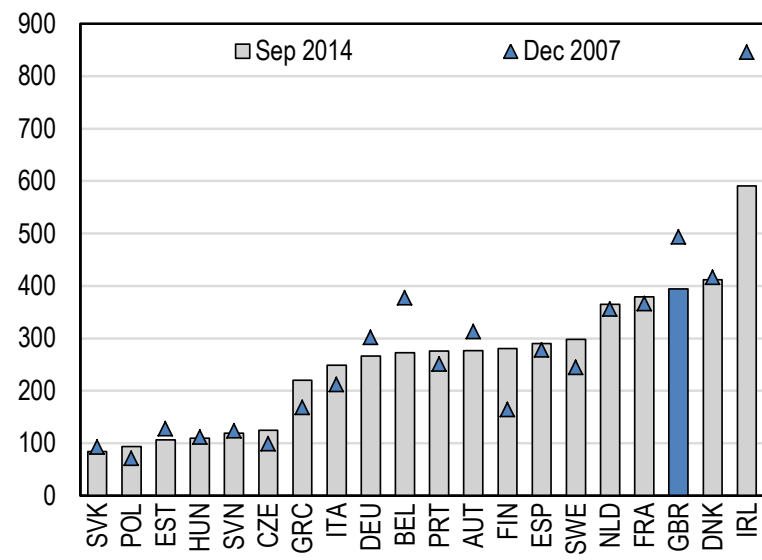

B. Loans to households and non-financial corporations $^{1}$

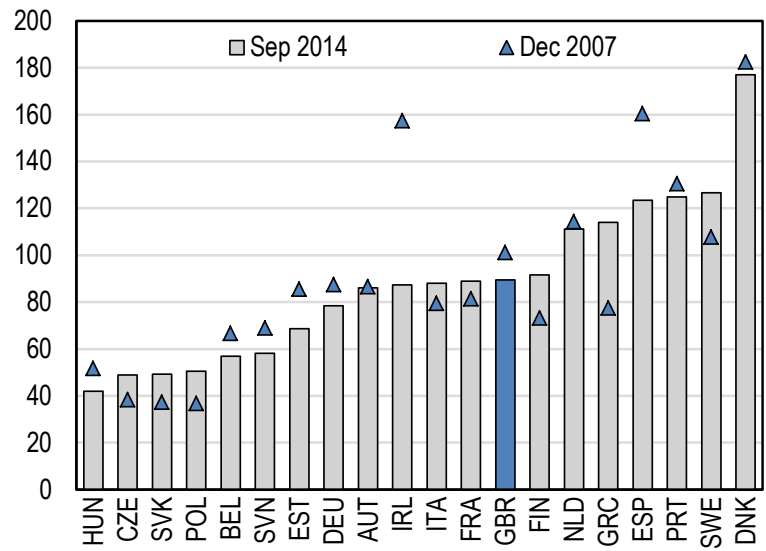

1. Outstanding stock of domestic loans of monetary financial institutions excluding European System of Central Banks (ESCB). Households include non-profit institutions serving households. January 2008 instead of December 2007 for Estonia.

Source: ECB (2015), "MFI Balance Sheets", Statistical Data Warehouse, European Central Bank, January and OECD (2015), OECD Economic Outlook: Statistics and Projections (database), January. 


\section{ECO/WKP(2015)63}

Despite the large size of the UK banking sector measured by total assets to GDP (Figure 14), loans to residents amount only to 30\% of banks' balances sheets (Table 3). Large parts of assets and liabilities represent relationships with non-residents (around 40\% of assets and liabilities) and monetary financial institutions (nearly $10 \%$ of assets and liabilities). Such structure of banks' balance sheets explains why, despite having one of the largest banking sectors in the world, firms experience credit constraints and the ratio of loans to enterprises to GDP remains below the OECD average (Figure 15). The low ratio would also be partly driven by more developed non-bank finance. However, as UK banks appear to be good in transactional lending to large enterprises and non-residents and in providing standardised mortgages to households, they appear less specialised in establishing relationships with SMEs.

Table 3. The structure of the UK banks' balance sheets

September 2014

\begin{tabular}{|c|c|c|c|c|c|}
\hline \multicolumn{3}{|l|}{ Assets } & \multicolumn{3}{|c|}{ Liabilities and capital } \\
\hline & $\begin{array}{c}\text { GBP } \\
\text { billion }\end{array}$ & $\%$ & & $\begin{array}{c}\text { GBP } \\
\text { billion }\end{array}$ & $\%$ \\
\hline Cash and central bank & 304 & 4 & Deposits from MFls & 441 & 6 \\
\hline $\begin{array}{l}\text { Loans to monetary financial institutions } \\
\text { (MFIs) }\end{array}$ & 439 & 6 & Resident deposits & 2143 & 30 \\
\hline Loans and advances to residents & 2039 & 29 & Non-resident deposits & 2086 & 29 \\
\hline Loans and advances to non-residents & 1888 & 27 & Repos & 939 & 13 \\
\hline Bills including Treasury bills & 46 & 1 & of which UK MFIs & 161 & 2 \\
\hline Repos & 1057 & 15 & UK residents & 229 & 3 \\
\hline of which UK MFIs & 153 & 2 & Non-residents & 550 & 8 \\
\hline UK residents & 268 & 4 & CDs and other paper issued & 649 & 9 \\
\hline non-residents & 636 & 9 & Capital and other internal funds & 587 & 8 \\
\hline Investments & 993 & 14 & Other & 268 & 4 \\
\hline of which UK public sector & 124 & 2 & & & \\
\hline UK MFIs & 63 & 1 & & & \\
\hline Residents & 273 & 4 & & & \\
\hline Non-residents & 533 & 7 & & & \\
\hline Other & 347 & 5 & & & \\
\hline Total assets & 7113 & & & & \\
\hline
\end{tabular}

Source: Bank of England (2015), "Monetary and Financial Statistics", Bankstats, January.

The recent global crisis has demonstrated that banks which are too big to fail benefit from implicit government guarantees. Despite important regulatory reforms since the last crisis, in 2013 markets still expected state intervention in the event of another crisis. The International Monetary Fund (IMF) has estimated that mean implicit subsidy for UK systemically important banks ranged from 20 to 60 basis points in 2013 and almost 75 basis points for large distressed banks (IMF, 2014b). This estimate is lower than during the immediate post-crisis period and lower than in the euro-area (60 to 90 basis points), but higher than in the US (15 basis points). 
Figure 15. Loans to non-financial corporations are low and are high for households

Per cent of GDP, September $2014^{1}$

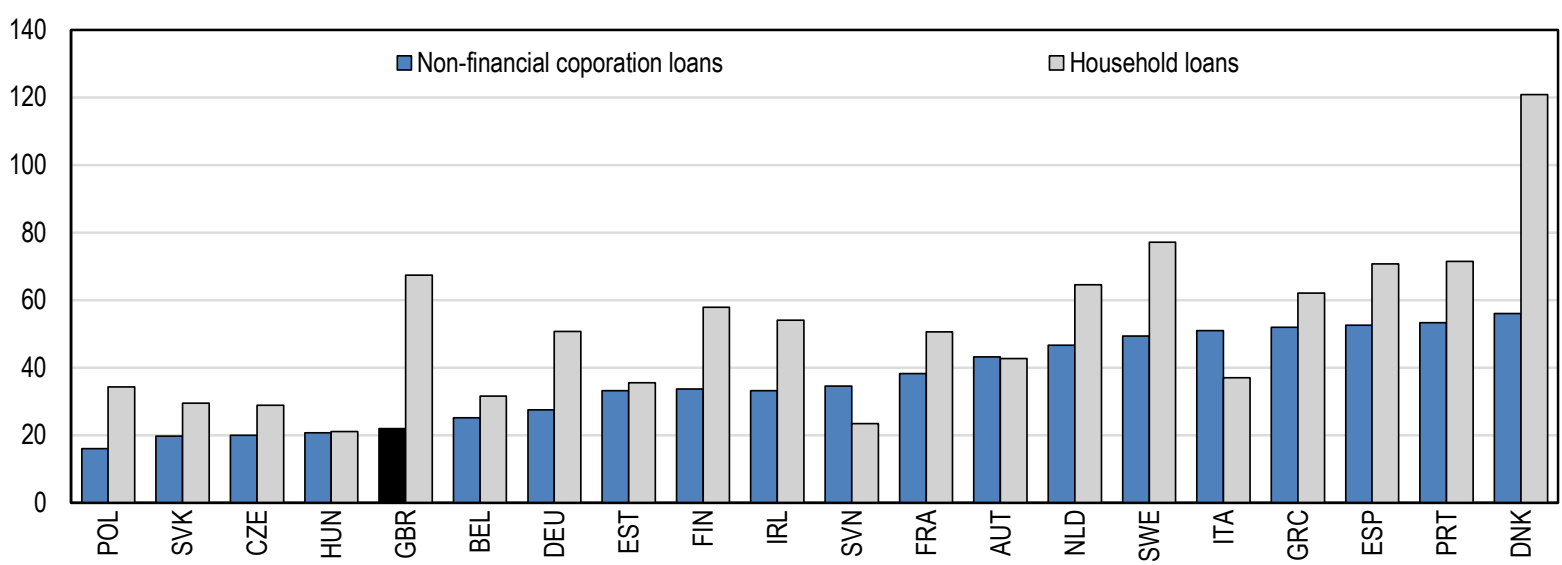

1. Outstanding stock of domestic loans from monetary financial institutions excluding European System of Central Banks (ESCB). Households include non-profit institutions serving households.

Source: ECB (2015), "MFI Balance Sheets", Statistical Data Warehouse, European Central Bank, January and OECD (2015), OECD Economic Outlook: Statistics and Projections (database), January.

Implicit government guarantees could be contained through high capitalisation, and credible bail-in and other resolution regimes. The UK was one of the first countries in the world to put in place a Special Resolution Regime (SRR) for failing banks in 2009 and this regime has most recently been amended in accordance with the Bank Recovery and Resolution Directive (adopted by the European Parliament in April 2014). The BoE has bail-in and other resolution powers and is responsible for the development of resolution strategies and plans and their execution for all banks (Gracie et al. 2014). To complement Basel III capital requirements, progress has been made at the international level with the recent proposals of the Financial Stability Board to strengthen the total loss absorbing capacity (both capital and certain liabilities) which could be used for the resolution of global systemic banks (BoE, 2014d). Arrangements for deposit protection and resolution will be met through an existing levy on financial institutions, with the money raised not being accrued in a specific fund (as in most other European countries) but in the general government budget.

\section{There is growing discussion about the optimal size of the banking sector}

The UK banks' assets could double in size and exceed nine times GDP by 2050 (Carney, 2013; Bush et al., 2014), which would require tight supervision and regulation to offset potential risks. There is a growing discussion about the optimal size of the banking sector and its impact on economic growth and inequality. Recent studies suggest that although finance enhances growth, there is a turning point somewhere between $80 \%$ and $100 \%$ of private credit to the real economy to GDP (Cecchetti and Kharroubi, 2012; Arcand et al., 2012).

A recent OECD study has also identified a marginal negative relationship between large intermediated credit and growth for a range of countries, including the UK (Schich et al., 2014). A potential explanation for the negative link between finance and growth after a certain threshold could be related to decreasing returns, misallocation of credit and an increase of macroeconomic or systemic risks (Bijlsma and Dubovik, 2014; Schich et al., 2014). There is also some evidence that financial sector development could reflect a misallocation of skilled labour to the financial sector at the expense of other sectors that require skilled workers (Cecchetti and Kharroubi, 2014). Moreover, recent empirical evidence suggests that only credit to enterprises may benefit growth, while credit to households may have no impact on growth 
(Beck et al., 2012). A large share of household lending that is related to high house prices might crowd out enterprise lending (Chakraborty et al., 2014).

\section{Enhancing capital buffers of large banks}

To contain risks posed by big banks, the FPC has proposed to strengthen capital requirements of UK banks by raising the leverage ratio (capital to unweighted assets) from $3 \%$ to $4.05 \%$ for large banks (Figure 16), to be enforced for global systemically important banks from 2016 and for other major banks from 2019. Also, regulatory authorities have requested from the government the power to impose a counter-cyclical leverage buffer, which would bring the overall leverage ratio for global systemic banks to almost 5\% in a boom when applying Basel III standards. However, there is no limit to the level the FPC might wish to set this buffer.

\section{Figure 16. The leverage ratio framework in the United Kingdom}

Per cent ${ }^{1}$

- Minimum leverage ratio

A. Risk-weighted countercyclical buffer (CCB) not activated

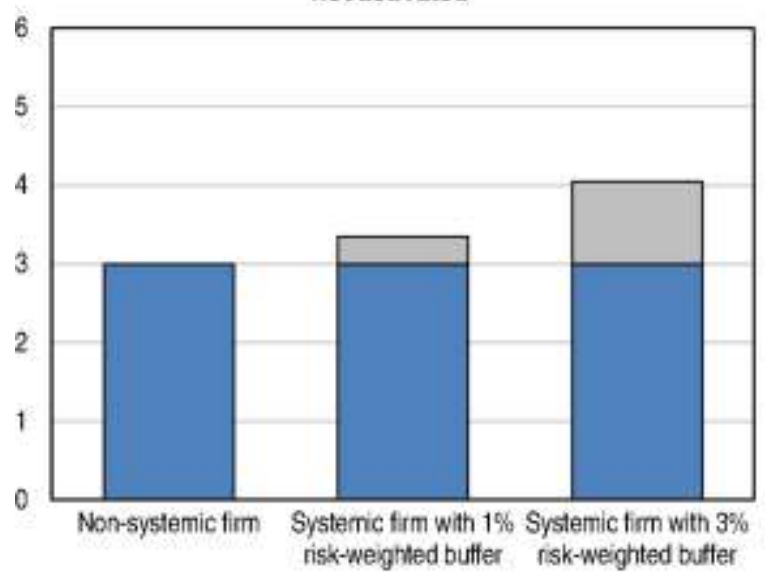

DCountercyclical leverage ratio butter (CCLB)

B. Risk-weighted countercyclical buffer (CCB) set to $2.5 \%$

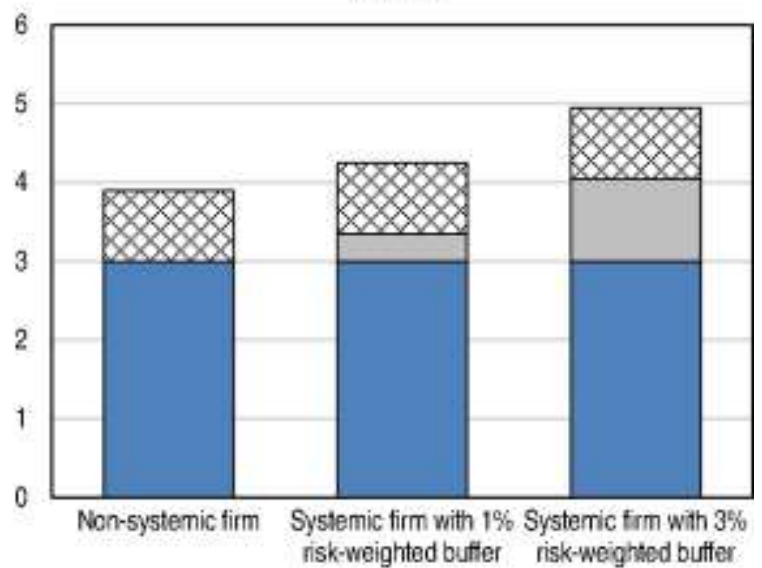

1. Countercyclical leverage ratio buffer (CCLB) show an example of the size of the CCLB for a bank with UK exposures only.

Source: Bank of England (2014), "The Financial Policy Committee's Review of the Leverage Ratio", October.

The proposed leverage ratio would go beyond Basel III regulations and complement risk-weighted capital ratios. In particular, a leverage ratio would insure against the risk of meeting regulatory ratios by lowering risk weights that often appear to be inconsistent and subject to manipulations (Le Leslé and Avramova, 2012; Haldane 2012; FSA, 2010; ICB, 2011). The problem of low risk-weighting of some assets was already addressed by the asset quality review of the PRA. As a result, floor loss-given defaults (the share of an asset that is lost when a borrower defaults) were imposed on residential and commercial real estate lending and sovereign lending, which should increase risk weights. Nevertheless, it is important for the PRA to undertake further analysis of banks' internal models and data sources to assess their robustness and their impact on risk measures.

The proposed leverage framework would represent significant progress, but systemically important banks would need to have a higher leverage ratio than 3-5\% to withstand a shock of the magnitude of the recent crisis. The FPC has announced that it will review the proposed leverage framework in 2017, to reflect progress in enforcing the international standard for a minimum leverage ratio expected in 2018. During the global crisis, total write-downs in the UK amounted to more than $5 \%$ of total assets (Miles et al., 2013) and the cost of the Treasury support reached $17 \%$ of banks' total balances sheet at the 
peak, including state guarantees. Global systemically important banks would have needed between three to four times more capital before the crisis to obviate the need for capital injections by private and public investors and liquidity support on a massive scale by the world's central banks (Blundell-Wignall et al., 2014).

The BoE's earlier research has shown that a stable banking sector requires a leverage ratio between $4 \%$ and $7 \%$ (Haldane, 2012) or between 7\% and 10\% (Miles et al., 2013). In particular, Miles et al. (2013) evaluate the cost and benefits of a higher leverage ratio by taking into account a range of factors including its impact on average cost of bank funding, probability of banking problems and the scale of the economic costs generated by banking sector problems. Following the crisis, international experts advocate leverage ratios with values around or even much higher than 10\% (Admati and Hellwig, 2013; Ratnovksi 2013; Wolf, 2014). Aiyar et al. (2015) propose a $10 \%$ book equity-to-asset ratio with a further requirement to issue $10 \%$ of assets in contingent capital (CoCos) that could be converted from debt into equity if the market value of equity relative to assets falls below a critical ratio. Finally, Blundell-Wignall and Roulet (2013) propose a leverage ratio of 5\%, but this level of ratio is conditional on a credible reform of a ring-fencing retail banking and withdrawing all implicit government subsidies for investment banking (Blundell-Wignall et al. 2014). Yet, systemic banks continue to benefit from implicit government guarantee (IMF, 2014b). Further progress in strengthening banks' financial buffers and resolvability including an ambitious and full implementation of the FPC's leverage framework in 2019, total loss-absorbing capacity requirements for major banks, and ring-fencing regime (see below) - should further lower implicit government subsidies. Ultimately, if these reforms prove insufficient, capital should be increased until the implicit government subsidy disappears.

Stricter capital requirements raise concerns that this could be costly for banks and economic growth. In the face of higher post-crisis capital requirements, banks have decreased their supply of loans and divested non-core activities (Aiyar et al. 2014; Bridges et al., 2014). This has happened despite the PRA request to ensure that all plans to address capital shortfalls do not reduce lending to the real economy. Since lending to non-financial corporations other than real estate companies amounts to only about $3.5 \%$ of banks' assets, the fall in lending cannot be explained by higher capital requirements. Banks could have shielded lending to firms from deleveraging by reducing non-core banking activities instead.

Higher capital requirements might support medium-term growth by reducing risks. Simulations by the Bank for International Settlements indicate that each 1 percentage point increase in the capital ratio raises loan spreads by 13 basis points, but the net impact on growth is positive due to enhanced resilience of the financial sector and lower crises probability (BIS, 2010). In the same vein, Miles et al. (2013) show that doubling of leverage from 5\% to $10 \%$ would increase funding costs by around 10-40 basis points as capital is more expensive than debt, but substantially higher capital requirements would reduce the probability of systemic banking crises - crises which are very costly (Reinhart and Rogoff, 2009).

Beyond regulatory requirements to boost banks' capitalisation, equity financing could be made less costly. Recent cuts in the corporate income tax from 30\% in 2007 to $20 \%$ in 2015 have significantly reduced the cost of capital. A further step would be to review tax advantages related to debt financing as is proposed by the Mirrlees Review (Mirrlees et al., 2011) and is operational in Belgium, Brazil and Latvia (Haldane, 2011b; De Mooij, 2012). This could be achieved either by reducing the tax deductibility of debt interest or by allowing firms to deduct from profits an allowance for corporate equity, provided the reform is implemented in a way that does not lead to tax base erosion and profit shifting from other countries (OECD, 2013). The fiscal cost of an allowance for corporate equity could reach $0.5 \%$ of GDP if applied to all firms and not only banks (De Mooij, 2012), but it could be reduced in the short run by granting the allowance only on new capital. 


\section{Better provisioning and prudent stress-testing are needed}

Sufficient provisioning for problem loans would further strengthen financial buffers of banks. As in many OECD countries, there is no standard definition of non-performing loans. However, the European Banking Authority (EBA) issued a definition for regulatory reporting in 2014. The regulator should provide guidance on the implementation of the new definition and strengthen data collection for different types of borrowers and loans. More generally, supporting international efforts for the creation of a common regulatory scale for asset classification system (beyond the classification of non-performing loans) would be an additional step forward. It is also necessary to collect information about restructured loans and to design requirements to write-off non-performing loans after a specified period to prevent forbearance and insufficient provisioning. Provisioning for losses is made in accordance with International Accounting Standards (i.e. on the incurred losses basis), which does not take into account expected losses on still performing or restructured loans. The regulator should also encourage banks to make preparations for the adoption of the forward-looking "expected loss" impairment model in international accounting standards, which is expected to come into force in 2018. Once the new accounting standards apply, subjecting banks to a minimum level of specific and general provisions for loans would further support adequate appraisal of risk.

In 2014, four major UK banks were stress-tested within the European Union-wide exercise and they all withstood the tests, although one bank was very close to the threshold. Also, the BoE undertook another stress-test of eight major UK banks and building societies as a variant of the EBA stress-testing exercise (BoE, 2014e). The stress scenario implemented by the UK authorities was based on end-2013 balance sheets covered the period between 2014 and 2016 and involved housing and commercial real estate price declines (respectively by $35 \%$ and $30 \%$ ) and a rise in the bank rate (to $4 \%$ in 2016), accompanied by a decline in equity prices (almost 30\%) and GDP (real GDP troughs at about 3.5\% below its last quarter 2013 level in late 2015), as well as a sharp rise in the unemployment rate (to 12\%), inflation (to 6.5\%) and depreciation of sterling (by $30 \%$ ).

The results of this 2014 stress-test, published in mid-December 2014, show that most UK banks can withstand above shocks. Three out of eight participating banks needed to strengthen their capital position, but given progress during 2014 and concrete plans to build capital further going forward, only one bank needed to submit a revised capital plan. Yet, the outcome of the stress-tests depends on the methodology and scenarios used. For instance, the $\mathrm{BoE}$ - in line with the approach taken by regulators internationally to conduct stress tests and set capital requirements - relies on the book value of bank equity. Using its market value and applying the methodology proposed by Acharya et al. (2012) shows that the UK financial system (including banks) could face an important capital shortfall in the case of another global crisis (Figure 17).

In the future and consistent with the BoE's medium-term plans, stress tests should involve a larger number of banks, include large non-banks and comprise a wider set of stress scenarios. The scenario for the 2014 stress-testing exercise appears rather demanding for almost all variables when compared to the UK past experience (BoE, 2014e). Such hypothetical scenario could be usefully complemented by more adverse macroeconomic and financial conditions that followed more severe banking crises in other countries. Importantly, the sharp increase in bank rate is nominal, but the real interest rate remains negative, which is benign from a historical perspective. A larger set of scenarios should be considered that range from high real interest rates to a "Japanese" scenario of low growth and deflation. In addition, stress-testing of liquidity shocks should be undertaken, as the Federal Reserve does. Interconnectedness with other banks and non-banks should be addressed by creating a scenario in which a systemically important institution fails, or there is a run from other monetary financial institutions or the repo market. To reduce uncertainty, results of the stress-testing exercise should continue to be made publicly available on the individual bank level. 
Figure 17. Global systemic risk of the UK financial sector is large

Capital shortage in case of $40 \%$ fall in the stock prices, USD billion ${ }^{1}$
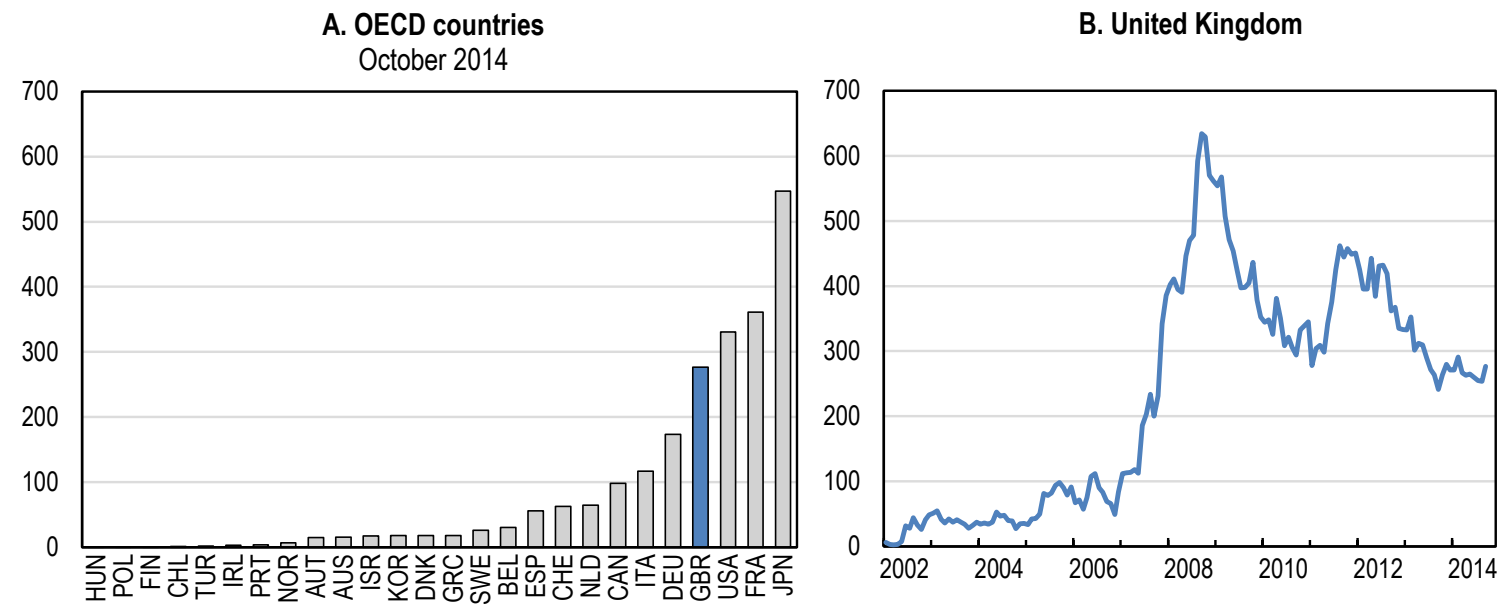

1. Global systemic risk (SRISK) is measured by the methodology proposed by Acharya et al. (2012). For the United Kingdom, financial sector includes major banks and the London Stock Exchange.

Source: New York University Stern School of Business, The Volatility Laboratory (V-Lab).

It is also important to consider second-round effects of different shocks. For instance, the impact of rising interest rates on banks' health should take into account the feedback effect on households. Household surveys show that an increase of interest rate by 1 percentage point would affect a quarter of households, while an increase of 4 percentage points would affect more than $60 \%$ of households (Bunn et al. 2013). In response to an interest rate increase in line with market expectations, the proportion of households spending more than one-third of their income on mortgage debt repayments (usually considered as a high leverage) would increase from about $15 \%$ to more than $25 \%$ (Blacklock and Whittaker, 2014). The increase would be the largest in London, from almost $20 \%$ to $35 \%$. The BoE considers that rising the policy rate from its current low level will not have unusually large effects on household spending (Anderson et al., 2014).

\section{Ring-fencing retail banking activities of large banks}

The aim of the recent structural reform to ring-fence retail banking activities of large banks (with more than GBP 25 billion of core deposits) is to separate banks' core activities from their investment activities. This should increase bank resolvability as the supervisor will have a better picture of banks' core activities that need to be protected during a crisis and will have more options for how to resolve a bank that is facing problems (for example by making it possible to keep the ring-fenced bank running even if its wider group fails). The framework was set out in the Financial Services (Banking Reform) Act 2013 and the mechanism of its implementation is currently under consultations launched by the PRA. The Act defines which activities are considered as core and need to be ring-fenced (deposit taking from individuals and small enterprises) and which are risky activities (such as proprietary trading) that cannot be undertaken by ring-fenced bodies. A large part of activities, such as deposit-taking from high net worth individuals and medium and large businesses can be carried out by either part of the bank. Currently, the PRA is consulting on the height of the ring-fence that will determine the degree of separation between the ring-fenced entity and the rest of the group in terms of transfer of capital and funding.

The height of the ring fence will have implications on the amount of activities that will be conducted by the ring-fenced entity. The height of the ring-fence (the ease with which banks can transfer capital and funding between ring-fenced and non-ring-fenced entities) would be set at an appropriate level. A too low 
ring-fence would incentivise banks to carry most of their activities inside the fence if ring-fencing is perceived to be an implicit government guarantee. A too high ring-fence would render ring-fenced entities more risky because of less risk-diversification with an excessive focus on mortgages and vulnerability to swings in house prices. This is problematic because the aim of ring-fencing is to shield the ring-fenced bank from risk arising elsewhere in the financial system. Moreover, the height of the ring-fence will also determine the extent of the ring-fenced entity's exposure as a creditor to the non-ring fenced entity. Therefore, applying additional capital buffers similar to systemic banks subject to a 3\% risk-weighted buffer (Figure 16) as decided by the authorities may be appropriate.

\section{Improving banks' resolvability}

The biggest banks are not only important as a share of GDP, but their structure is also extremely complex. The four largest UK banks have altogether more than 5000 subsidiaries, a third of them located in offshore financial centres. Little public information exists about the nature of banking activities in these territories, and such information is important to prevent that large risks migrate to jurisdictions with light supervision. However, following recent developments in European legislation (Capital Requirement Directive 4) banks have been required to disclose information on subsidiaries such as the name of establishment, nature of activities and geographical location, turnover, number of employees, profit or loss before tax, tax on profit or loss and public subsidies received from January 2015. Greater transparency would be ensured if banks also had to provide information on total assets held in offshore financial centres. It is important for the BoE to carefully consider the impact of complex banking structures on banks' resolvability and require banks to undertake action if needed.

\section{Other supervisory challenges}

\section{Further extending regulatory oversight beyond the banking sector}

New credit providers (peer-to-peer, crowdfunding and direct lending funds) offer new opportunities in terms of broadening access to finance, but they also create new risks for investors. There are a number of differences between these providers and traditional banks. The former do not perform maturity transformation as lenders/investors have to pre-commit their money for a certain period of time. They function without leverage and losses are imposed directly on investors. Hence, they differ from what is normally called "shadow banking" (Box 5). Some peer-to-peer platforms provide ratings to small businesses allowing a simpler match between lenders and borrowers, but risks and eventual losses are born by lenders, while the fee income of the platform depends on the volume of transactions. This could lead to agency problems and could result in inadequate client screening.

\section{Box 5. Definitions of shadow banking}

\section{Definition of the Financial Stability Board (FSB, 2014)}

The FSB provides two definitions of shadow banking. According to the broad measure definition, non-bank financial intermediation is measured by total financial assets held by Other Financial Intermediaries (OFIs), which include all non-bank financial intermediaries with the exception of insurance companies, pension funds and public financial institutions. In other words, this measure includes market funds, finance companies, structured finance vehicles, hedge funds, other investment funds, broker-dealers, real-estate investment trusts and funds.

The narrow measure definition focuses on the subset of non-bank credit intermediation which potentially poses systemic risks to the financial system. It includes financial assets of OFIs minus i) financial assets of non-bank financial entities not involved in bank-like credit intermediation; ii) Financial assets related to those non-bank financial entities that are prudentially consolidated into a banking group; iii) Financial entities whose activities do not exhibit risks associated with shadow banking including but not limited to maturity and liquidity transformation, and/or leverage. In the wake of the crisis, the institutional structure of the UK financial regulation and supervision has been revamped by the Financial Services Act, which came in force in April 2013. The Act discontinued the Financial Services Authority and has expanded the responsibilities of the Bank of England, which rests on three pillars. 


\section{Definitions of shadow banking (cont.)}

\section{Definition of the International Monetary Fund (IMF, 2014c)}

The definition of the IMF of the shadow banking is based on non-traditional (noncore) funding. In this "activity" concept, shadow banking is measured by the size of noncore liabilities both from banks and from "other financial corporations" (including money market funds, MMF), except insurance companies, pension funds, and non-MMF investment funds. The main financial instruments that are considered to be components of noncore liabilities are debt securities, loans, MMF shares, and a small portion of restricted deposits (that is, deposits excluded from broad money).

A narrow measure of noncore liabilities excludes those confined to the financial sector; it is thus a proxy for the intermediation between ultimate lenders and ultimate borrowers - that is, between the financial sector and the real economy. The difference between the broad and narrow measures represents an estimate of the amount of credit intermediation conducted within the shadow banking sector.

The appearance of direct lending funds could lead to new forms of credit intermediation that could be less fragile than banks. Asked about the future of direct lending funds, some asset managers have in mind credit intermediation activities without maturity transformation or leverage, such as a loan fund that locks in investors for a few years and so is not subject to liquidity risk (IMA, 2012). Hence, these direct lending funds resemble a theoretical proposal of limited-purpose banking to reduce banks' fragility and moral hazard (Chamley et al., 2012). However, their net present value is uncertain because they invest in illiquid credit.

The authorities should watch closely if excessive risks migrate from regulated banks to other credit providers and prepare for possible spillover effects back to banks. Indeed, it appears that traditional banks may be shifting to less risky credit, while investment funds and peer-to-peer platforms may have been providing credit to riskier borrowers. Some banks have started engaging with alternative lenders, such as asset management firms, to bolster lending to riskier companies. One example includes provision of so-called "unitranche" debt, a blend of senior and more junior and riskier loans bearing a single interest rate. Although the borrower will face one loan with one interest rate, the bank will be reimbursed first, and hence, the investment fund will carry more risk. In this situation, investment funds benefit from banks' network of clients and their ability to provide ancillary services, such as hedging. Some banks also start to co-operate with peer-to-peer platforms.

Macro-prudential tools of the FPC should gradually be extended beyond the banking sector to support the effectiveness of regulatory instruments so as to prevent that credit demand and systemic risk are channelled outside regulated banks. In the first place, this should apply to financial institutions that have access to liquidity instruments of the BoE. Broker-dealers are an important part of the shadow banking sector (Box 5) and have recently been allowed such access, but they could be prone to liquidity runs due to high leverage and the use of short-term secured lending arrangements, such as repos. Moreover, it is important for the regulator of alternative finance providers and traditional institutional investors (FCA) to collect information about the size of lending, risk profile, underwriting standards or credit conditions. This should be done in co-operation with the BoE as the regulator of traditional banking.

\section{Regulatory framework of the securitisation market should remain tight}

Although the BoE and the ECB (2014) attempt to revive the securitisation market to boost lending, particularly to SMEs, its regulation should remain tight. In the run-up to the crisis, the securitisation offered substantial advantages but contributed to the expansion of off-balance sheet activities of banks before the crisis (Figure 2) and contributed to the financial meltdown. A number of new regulations have been implemented recently to improve screening practices and to prevent regulatory arbitrage. First, banks are required to retain a part of their securitised loans to increase their incentives to adequately screen and monitor borrowers. This is important to prevent higher default rates on securitised loans in comparison to 
loans of the same risk profile, but which are held by banks on their balance sheets (Keys et al., 2010; Mian and Suffi, 2009). Second, capital requirements have been harmonised for loans on banks' balance sheets and in SPVs. This removes the possibility for regulatory arbitrage that was prevalent before the crisis when conduits were set up to avoid capital regulation. For example, Acharya et al. (2013) argue that due to SPVs, some British banks were able to reduce their capital requirements by up to $25 \%$.

\section{Improving corporate governance}

Recently, the banking industry has paid large amounts of fines and litigation costs, pushing banks to significantly increase their provisions. Total costs and provisions amounted to around GBP 35 billion or close to 2\% of GDP at the end of 2013 (Table 4). The Parliamentary Commission on Banking Standards (2013) describes banks' misconduct, such as miss-selling of interest rate swaps and payment protection insurance (PPI) products (insuring the repayment of loans) to small businesses and individuals, Libor manipulation, money-laundering and breach of sanctions. The largest part of these conduct costs are related to the PPI products and, according to the FCA, complaining customers have so far received GBP 15 billion (1\% of GDP) between January 2011 and April 2014 (against GBP 50 billion worth of PPI policies sold over the last ten to fifteen years). Two recent reports have described the treatment of distressed SMEs by some banks after the crisis, suggesting they may have maximised their profits by working sometimes against the best interests of financially distressed customers (Large, 2013; Tomlinson, 2013).

Table 4. Fines and settlements as well as provisions for litigation costs of banks have been high GBP billion, 2009-13 1

\begin{tabular}{lrrr}
\hline & Fines and settlement costs & Provisions as at 31 Dec 2013 & \multicolumn{1}{c}{ Total } \\
\hline United States & 71.73 & 41.67 & 113.40 \\
United Kingdom & 22.30 & 13.99 & 36.29 \\
Switzerland & 5.08 & 2.68 & 7.76 \\
Germany & 3.87 & 1.75 & 5.62 \\
Spain & 2.42 & 1.14 & 3.57 \\
\hline Total & 105.40 & 61.23 & 166.64 \\
\hline
\end{tabular}

1. Data for the United Kingdom refer to four banks. Data for Germany refer to one bank. Data for Spain refer to one bank. Data for Switzerland refer to two banks. Data for the United States refer to four banks.

Source: Conduct Costs Project 2012-2014.

A number of reforms have been implemented to improve banks' corporate governance and to align remuneration with risk. The PRA is introducing a "Senior Managers regime" for banks, which will replace the current "approved persons regime" and should ensure that key activities are tasked to individuals with direct responsibility for carrying them out. A new remuneration code, introduced in 2010, compels senior staff at banks to have $50 \%$ of variable remuneration paid in non-cash instruments, $40 \%$ of variable remuneration deferred over a period of 3 to 5 years and allows for the cancellation of bonuses that have not yet been awarded to individuals. Finally, a new criminal offence (carrying a prison sentence of up to 7 years) for "senior managers" has been introduced for reckless misconduct in the management of a bank leading to its failure. This is in line with the recommendation of the Parliamentary Commission on Banking Standards (2013).

These reforms of remuneration go in the right direction and more proposals are under consideration. Following public consultations, the PRA is currently considering retrospective imposition of the clawbacks on variable pay in certain circumstances. There are also proposals to index remuneration to returns on assets and not on returns on equity to limit the impact of leverage on remuneration (Haldane, 2011b). 


\section{Box 6. Policy recommendations to ensure sustainable lending and financial stability}

\section{Enhancing credit supply}

Ensure comprehensive data collection of credit information by credit reference agencies and its sharing with all credit providers and the Bank of England. Alternatively, create a central credit registry run by the Bank of England.

Consider transforming the British Business Bank into a permanent instrument of SME financing.

Encourage the development of and collect information on alternative finance providers and direct lending funds, including borrower's risk and profile, and underwriting standards.

\section{Mitigating credit cycles}

Continue to observe underwriting standards in mortgage lending and, if needed, broaden the use of macro-prudential tools. Further relax regulatory constraints to boost housing supply, in particular by thoroughly reviewing the boundaries of protected areas of the Green Belt.

Undertake further analysis of banks' internal ratings models (using data from credit reference agencies where appropriate) to ensure that risk weights adequately reflect systemic risks and are less pro-cyclical.

Gradually extend the Bank of England's regulatory oversight beyond the banking sector, notably by subjecting institutions that have recently been granted access to liquidity instruments (such as broker-dealers) to macro-prudential instruments of the Financial Policy Committee.

\section{Enhancing financial stability}

Consider higher leverage ratios for global systemic banks to complement risk-weighted capital ratios.

Encourage banks to start preparing for the adoption of the forward-looking "expected loss" impairment model from 2018. Support the development of a common regulatory scale for asset classification system at the international level.

Extend stress tests to a larger number of banks and other financial institutions and include a wider set of stress scenarios, such as a liquidity run and a collapse of a large institution.

Increase transparency about the presence of banks in off-shore financial centres by ensuring the publication of data on total assets.

\section{Bibliography}

André, C. (2011), "Improving the Functioning of the Housing Market in the United Kingdom", $O E C D$ Economics Department Working Papers, No. 867, OECD Publishing.

Acharya, V., P. Schnabl P and G. Suarez (2013), "Securitization Without Risk Transfer", Journal of Financial Economics, Vol. 107, No. 3, March.

Acharya, V., R. Engle, and M. Richardson (2012), “Capital Shortfall: A New Approach to Ranking and Regulating Systemic Risks", American Economic Review, Vol. 102, No. 3, May.

Admati, A. and M. Hellwig (2013), The Bankers' New Clothes: What's Wrong with Banking and What to Do About It, Princeton University Press.

Aiyar, S., C. Calomiris and T. Wieladek (2015), “A Primer on Bank Capital Regulation: Theory, Empirics, and Policy", IMF Economic Review, forthcoming. 
Anderson, G., P. Bunn, A. Pugh and A. Uluc (2014), "The potential impact of higher interest rates on the household sector: evidence from the 2014 NMG Consulting survey", Bank of England Quarterly Bulletin, Vol. 54, No. 4, Bank of England.

Arcand, J., E. Berkes and U. Panizza (2012), “Too Much Finance?”, IMF Working Papers, No. WP/12/161, International Monetary Fund, June.

BIS (2010), An Assessment of the Long-Term Economic Impact of Stronger Capital and Liquidity Requirements, Basel Committee on Banking Supervision, Bank for International Settlements.

Beck, T., B. Büyükkarabacak, F. Rioja and N. Valev (2012), "Who Gets the Credit? And Does it Matter? Household vs. Firm Lending across Countries", B.E. Journal of Macroeconomics: Contributions, Vol 12, No.1, March.

Bijlsma, M. and A. Dubovik (2014), "Banks, Financial Markets, and Growth in Developed Countries: A Survey of the empirical Literature", CPB Discussion Paper, No. 266, February.

Blacklock, K. and M. Whittaker (2014), Hangover Cure. Dealing with the household debt overhang as interest rates rise, Resolution Foundation Report, July.

Blundell-Wignall, A., P. Atkinson and C. Roulet (2014), "Bank business models and the Basel system: Complexity and interconnectedness", OECD Journal: Financial Market Trends, Vol. 2013/2, OECD Publishing.

Blundell-Wignall, A. and C. Roulet (2013), "Business Models of Banks, Leverage and the Distance-to default", OECD Journal: Financial Market Trends, Vol. 2012/2, OECD Publishing.

BoE (2014a), Inflation Report, Bank of England, May.

BoE (2014b), "Should the availability of UK credit data be improved?", A Discussion Paper, Bank of England, May.

BoE (2014c), Financial Stability Report, Bank of England, June.

BoE (2014d), Financial Stability Report, Bank of England, December.

BoE (2014e), Stress testing the UK banking system: key elements of the 2014 stress test, Bank of England, April.

BoE (2014f), The Bank of England's Approach to Resolution, October.

BoE and ECB (2014), "The case for a better functioning securitisation market in the European Union", $A$ Discussion Paper, Bank of England, European Central Bank, May.

Bridges, J., D. Gregory, G. M. Nielsen, S. Pezzini, A. Radia and M. Spaltro (2014), "The Impact of Capital Requirements on Bank Lending", Bank of England working papers, No. 486, Bank of England.

Brown, M. J. Tullio and M. Pagano (2009), "Information Sharing and Credit: Firm-Level Evidence from Transition Countries", Journal of Financial Intermediation, Vol. 18, No. 2, April.

Bunn, P., M. Rostom, S. Domit, N. Worrow and L. Piscitelli (2013), "The financial position of British households: evidence from the 2013 NMG Consulting survey", Bank of England Quarterly Bulletin, Vol. 53, No. 4, Bank of England.

Bush, O., S. Knott and C. Peacock (2014), "Why is the UK banking system so big and is that a problem?", Bank of England Quarterly Bulletin, Vol. 54, No. 4, Bank of England. 
Butt, N., R. Churm, M. McMahon, A. Morotz and J. Schanz (2014), "QE and the bank lending channel in the United Kingdom", Bank of England working papers, No. 495, September, Bank of England.

Carney, M. (2013), “The UK at the heart of a renewed globalization”, Speech given by at an event to celebrate the $125^{\text {th }}$ anniversary of the Financial Times, London, 24 October.

Cecchetti, S. and E. Kharroubi (2012), "Reassessing the impact of finance on growth", BIS Working Papers 381, Bank for International Settlements, July.

Cecchetti, S. and E. Kharroubi (2014), "Why does financial sector growth crowd out real economic growth?", mimeo, presented on Bundesbank-BoJ Conference "Common challenges in Asia and Europe", 2 May.

Chakraborty, I., I. Goldstein and A. MacKinlay (2014), "Do Asset Price Bubbles Have Negative Real Effects?", In revision for the Journal of Finance, September.

Chamley, C., L. Kotlikoff and H. Polemarchakis (2012), "Limited-Purpose Banking-Moving from "Trust Me" to "Show Me" Banking", American Economic Review: Papers \& Proceedings 2012, Vol. 102, Vol. 3, May.

Claessens, S., S. Ghosh and R. Mihet (2013), "Macro-prudential policies to mitigate financial system vulnerabilities", Journal of International Money and Finance, Vol. 39, December.

CMA and FCA (2014), Banking services to small and medium-sized enterprises: a CMA and FCA market study, Financial Conduct Authority, Competition \& Markets Authority.

Collins, L., R. Swart and B. Zwang (2013), The rise of future finance. The UK Alternative Finance Benchmarking Report.

Crowe, C., G. Dell'Ariccia, D. Igan and P. Rabanal (2011), "How to Deal with Real Estate Booms: Lessons from Country Experiences", IMF Working Paper, No. WP/11/91, April.

De Mooij, R. (2012), "Tax Biases to Debt Finance: Assessing the Problem, Finding Solutions”, Fiscal Studies, Institute for Fiscal Studies, Vol. 33, No. 4, December.

FCA (2013), Findings of Review into Interest-Only Mortgages, Financial Conduct Authority.

FPC (2014), “The Financial Policy Committee's powers to supplement capital requirements”, A Policy Statement, Financial Policy Committee, Bank of England, January.

FSA (2010), Results of 2009 Hypothetical Portfolio Exercise for Sovereigns, Banks and Large Corporations, Financial Services Authority, March.

FSA (2011), The failure of the Royal Bank of Scotland, Financial Services Authority Board Report, December.

FSB (2014), Global shadow banking monitoring report, Financial Stability Board, November.

GfK (2013), Interest only mortgages. Consumer research - consumer strategies for repaying the loan at the end of the mortgage term, Growth From Knowledge.

Gracie, A., L. Chennells and M. Menary (2014). "The Bank of England's approach to resolving failed institutions", Bank of England Quarterly Bulletin, Vol. 54, No. 4, Bank of England. 
Grjebine, T., U. Szczerbowicz and F. Tripier (2014), "Corporate Debt Structure and Economic Recoveries", CEPII Working Paper, N²014-19, November.

Haldane, A. (2010), "Curbing the credit cycle", speech presented by at the Columbia University Center on Capitalism and Society Annual Conference, New York, 20 November.

Haldane, A. (2011a), "Capital Discipline", based on a speech given at the American Economic Association, Denver, 9 January 2011.

Haldane, A. (2011b), "Control rights (and wrongs)", speech given at the Wincott Annual Memorial Lecture, Westminster, London, 24 October.

Haldane, A. (2012), “The dog and the Frisbee”, speech given at the Federal Reserve Bank of Kansas City's 36th economic policy symposium, "The Changing Policy Landscape", Jackson Hole, Wyoming, 31 August 2012.

Haldane, A. (2013), "Why institutions matter (more than ever)", speech given at the Stability Centre for Research on Socio-Cultural Change (CRESC) Annual Conference, School of Oriental and African Studies, London, 4 September 2013

Haldane, A. (2014), “Ambidexterity”, Speech delivered at the American Economic Association Annual Meeting, Philadelphi, 3 January 2014.

Havrylchyk, O. (2015), "Incentivising lending to SMEs within a funding-for-lending scheme: Some evidence from bank data", OECD Economics Department Working Papers, forthcoming.

Hoshi, T. and A.K. Kashyap (2010), "Will the U.S. Bank Recapitalization Succeed? Eight Lessons from Japan”, Journal of Financial Economics, Vol. 97, No. 3, September.

ICB (2011), Final Report Recommendations, Independent Commission on Banking, September.

IMA (2012), Asset Management in the UK 2011-2012. The IMA annual survey, Investment Management Association.

IMF (2014a), “United Kingdom - 2014 Article IV Consultation”, IMF Country Report, No. 14/233, July.

IMF (2014b), Moving from Liquidity- to Growth-Driven Markets, Global Financial Stability Report, International Monetary Fund, April.

IMF (2014c), Risk Taking, Liquidity, and Shadow Banking: Curbing Excess While Promoting Growth, Global Financial Stability Report, International Monetary Fund, October

Infelise F. (2014), "Supporting Access to Finance by SMEs: Mapping the initiatives in five EU countries", ECMI Research Report, No. 9, April.

Jiménez, G., S. Ongena, J. Peydró and J. Saurina (2014), "Hazardous times for monetary policy: What do twenty-three million bank loans say about the effects of monetary policy on credit risk?", Econometrica, Vol. 82, No. 2, March.

Joyce, M., M. Tong and R. Woods (2011), “The United Kingdom's quantitative easing policy: design, operation and impact", Bank of England Quarterly Bulletin, Vol. 51, No. 3, Bank of England.

Keys, B., T. Mukherjee, A. Seru, V. Vig (2010), "Did securitization lead to lax screening? Evidence from subprime loans", The Quarterly Journal of Economics, Vol. 125, No. 1, February. 
Kuttner, K. and I. Shim (2013), "Can non-interest rate policies stabilise housing markets? Evidence from a panel of 57 economies", BIS Working Papers, No. 433, November.

Large, A. (2013), RBS Independent Lending Review, November.

Le Leslé, V. and S. Avramova (2012), "Revisiting Risk-Weighted Assets: Why do RWAs Differ Across Countries and What Can Be Done About It?", IMF Working Paper No. WP/12/90, May.

Mian, A. and A. Suffi (2014), House of Debt: How They (and You) Caused the Great Recession, and How We Can Prevent It from Happening Again, The University of Chicago Press.

Mian, A. and A. Suffi (2009), "The Consequences of Mortgage Credit Expansion: Evidence from the U.S. Mortgage Default Crisis”, The Quarterly Journal of Economics, Vol. 124, No. 4, November.

Miles, D, J. Yang and G. Marcheggiano (2013), “Optimal Bank Capital”, The Economic Journal, Vol. 123, No. 567, March.

Mirrlees, J., S. Adam, T. Besley, R. Blundell, S. Bond, R. Chote, M. Gammie, P. Johnson, G. Myles, J. Poterba (2011), "The Mirrlees Review: Conclusions and Recommendations for Reform", Fiscal Studies, Institute for Fiscal Studies, vol. 32, No. 3OBR (2014), Economic and Fiscal Outlook, Office for Budget Responsibility, December.

OECD (2014), Financing SMEs and Entrepreneurs 2014: an OECD Scoreboard, OECD Publishing.

OECD (2013a), OECD Economic Surveys: United Kingdom 2013, OECD Publishing.

OECD (2013b), Addressing Base Erosion and Profit Shifting, OECD Publishing.

OECD (2011), OECD Economic Surveys: United Kingdom 2011, OECD Publishing.

Öztürk, B. and M. Mrkaic (2014), "SMEs' Access to Finance in the Euro Area: What Helps or Hampers?", IMF Working Paper, No. 14/78, May.

Parliamentary Commission on Banking Standards (2013), Changing banking for good, Report of the Parliamentary Commission on Banking Standards.

Ratnovski, L. (2013), “How much capital should banks have?”, VoxEU, 28 July 2013.

Reinhart, C. and K. Rogoff (2009), This Time is Different - eight centuries of financial folly, Princeton University Press.

Shakir, T. and M. Tong (2014), "The interaction of the FPC and the MPC", Bank of England Quarterly Bulletin, Vol. 54, No. 4, Bank of England.

Schich, S., B. Cournède and O. Denk (2014), "Finance and Inclusive Growth”, Working Party No. 1 on Macroeconomic and Structural Policy Analysis, OECD.

Shin, H. (2009), "Reflections on Northern Rock: The Bank Run That Heralded the Global Financial Crisis", Journal of Economic Perspectives, Vol. 23, No. 1, Winter.

Smith, L. (2008), The Lloyds-TSB and HBOS Merger: Competition Issues, House of Commons Library, Standard Note: SN/BT/4907, December.

Tomlinson, L. (2013), Banks' Lending Practices: Treatment of Businesses in distress, Entrepreneur in Residence at the Department for Business, Innovation and Skills. 
ECO/WKP(2015)63

Wolf, M. (2014), The Shifts and the Shocks: What We've Learned - and Have Still to Learn - from the Financial Crisis, London and New York: Allen Lane and Penguin. 